\title{
Prehistoric Cultures in Xinjiang: Retrospect and Prospect
}

\author{
By Marcella Festa*
}

\begin{abstract}
Archaeological researches in Xinjiang in the last century have revealed that the region was a crossroad of cultures as early as prehistory, but it is only in the last thirty years that its crucial importance has come to be recognized. From the 1980s an increasing number of studies have put forward cultural categories and spatialtemporal frameworks to organize Bronze Age and Iron Age remains in Xinjiang but due to several problems, such as scarce publications and scant reliable dating, there is still a lack of clear standards for establishing the cultural and temporal attributions of the sites. Nevertheless, the contribution given by debates among scholars on the subject is remarkable and needs to be evaluated in greater detail, in order to gain a clearer understanding of early Xinjiang. This paper aims to be a qualitative study on the current research on Bronze Age and Iron Age cultures in Xinjiang. It provides a retrospective review of the studies on the subject with special reference to selected works since the 1980s, in the hope of enhancing the understanding of Xinjiang and Eurasian prehistory.
\end{abstract}

\section{Introduction}

A series of excavations conducted during the last century in Xinjiang brought to light remains that were ascribed to the prehistory. Since then, an increasing number of objects has enriched the Urumqi Regional Museum, which, besides the famous "Tarim mummies", currently hosts a rich collection of remains from the whole region ${ }^{1}$.

* PhD Candidate, Ca' Foscari University of Venice, Italy.

1. The Urumqi Regional Museum, founded in 1953, hosts most of the ancient naturally embalmed corps found in the southern part of Xinjiang, and different objects, mostly pottery vessels, stone and metal items, and textiles. The collection, among others includes painted pottery from Hami and Turfan, stone and metal implements from the whole Xinjiang region, plaques from Yanghai and Shanshan cemeteries, textiles from the oasis of the southern Tarim basin. Some of the artefacts showed in this paper are currently displayed in the Museum. Additionally, interesting material is stored in the Xinjiang Institute of archaeology in Urumqi city, such as the olive-shaped jars from Qiemu'erqieke village, wooden implements and anthropomorphic figurines from Gumugou cemetery and pieces from Niya, Hami, Turfan and the Yili river region. A high number of "integrative" museums, built close to the most important ancient sites, host local artefacts, which are also of high interest. 
Table 1. Frameworks Proposed by Scholars for Cultural Groups in the Bronze Age

\begin{tabular}{|c|c|c|c|c|c|}
\hline & FRANCFORT & CHEN-HIEBERT & MEI JIANJUN & CHENG GE & HAN JIANYE \\
\hline $\begin{array}{l}\text { ALTAY } \\
\text { MOUNTAINS }\end{array}$ & & $\begin{array}{l}\text { Qiemu'erqieke (Kan'erzi } \\
\text { A'erkate - Mulei nan } \\
\text { Wulaboshuiku - Adongquele } \\
\text { A'ershate) }\end{array}$ & Qiemu'erqieke & & Qiemuerqieke I \\
\hline $\begin{array}{l}\text { YILI } \\
\text { VALLEY } \\
\text {-TACHENG } \\
\text { REGION }\end{array}$ & & & $\begin{array}{l}\text { Gongliu Aga'ersen (Sazi - } \\
\text { Weixiao) }\end{array}$ & Weixiao & $\begin{array}{l}\text { Laokeke } \\
\text { Sa'erbulake } \\
\text { Akebucaogou } \\
\text { Tacheng } \\
\text { Daxigou } \\
\end{array}$ \\
\hline \multirow{3}{*}{$\begin{array}{l}\text { NORTHERN } \\
\text { TIANSHAN } \\
\text { MOUNTAINS } \\
\text { TURFAN- } \\
\text { BARKOL } \\
\end{array}$} & Halahezhou & \multirow{3}{*}{\begin{tabular}{|l} 
Aidinghu (Subeixi - Biyugou \\
Kageqiake - Yinyailake)
\end{tabular}} & Halahezhou & Halahezhou & Halauy'ergou \\
\hline & $\begin{array}{l}\text { Nanwan (Lanzhouwanzi - Kuisu - } \\
\text { Kaersang) } \\
\text { Sidoogou }\end{array}$ & & $\begin{array}{l}\text { Nanwan (Lanzhouwanzi - } \\
\text { Shirenzi - Ka'ersang - Yanchi) } \\
\text { Sidaogou (Baniiegou) }\end{array}$ & $\begin{array}{l}\text { Nanwan (Lanzhouwanzi - Kuisu - } \\
\text { Shirenzi - Junmachang - Yanchi - } \\
\text { Ka'arsang) }\end{array}$ & $\begin{array}{l}\text { Liangzhongfang } \\
\text { Shuinichang }\end{array}$ \\
\hline & Mulei & & & Akesu (Halayu'ergun) & $\begin{array}{l}\text { Ka'erzang } \\
\text { Xigonggou }\end{array}$ \\
\hline \multirow{2}{*}{$\begin{array}{l}\text { SOUTHERN } \\
\text { TIANSHAN } \\
\text { MOUNTAINS }\end{array}$} & \multirow[t]{2}{*}{ Xintala (Quhui) } & \multirow{2}{*}{$\begin{array}{l}\text { Haladun (Aketala - Wengoloke } \\
\text { Kuluketala - Dawuoleke - Akesu } \\
\text { Halayu'ergun - Kujukejin } \\
\text { A kere ke - A ke bul a ke } \\
\text { Bogedaqing) }\end{array}$} & Xintala (Quhui) & \multirow{2}{*}{ Xintala (Quhui) } & $\begin{array}{l}\text { Quhui } \\
\text { Xintala }\end{array}$ \\
\hline & & & Haladun & & Haladun \\
\hline \begin{tabular}{l|l} 
EAST & $\mathrm{y}$ \\
XINJIANG & $\mathrm{L}$
\end{tabular} & $\begin{array}{l}\text { Wupu (Kezi'erqueqia } \\
\text { Lafuqiaoke-Yanbulake) }\end{array}$ & $\begin{array}{l}\text { Yanbulake (Yamansukuang } \\
\text { Lafuqiaoke - Wubaoshuiku } \\
\text { Haladun) }\end{array}$ & $\begin{array}{l}\text { Wupu } \\
\text { Tianshanbeilu } \\
\text { Yanbulake (Lafugiaoke) }\end{array}$ & & \\
\hline $\begin{array}{l}\text { EASTERN } \\
\text { TARIM } \\
\text { BASIN }\end{array}$ & Gumugou & Gumugou & Gumugou & Gumugou & Lop Nur \\
\hline \begin{tabular}{|l|l} 
PAMIRS & $A$ \\
HIGHLANDS & $\mathrm{H}$
\end{tabular} & $\begin{array}{l}\text { Aketala } \\
\text { Halayu'ergun) }\end{array}$ (Kuluketala & & $\begin{array}{l}\text { Suletnag'ba } \\
\text { Aketala (Halayu'ergun) }\end{array}$ & Aketala & Xiabandi \\
\hline \begin{tabular}{|l|} 
NORTHERN \\
KUNLUN \\
MOUNTAINS
\end{tabular} & & & & & Niya \\
\hline
\end{tabular}

Source: Author.

Prehistoric sites in Xinjiang were key-points for east-west exchanges, but it is only in the last thirty years that their crucial importance has been recognized. Indeed, from the 1980's more systematic studies on Xinjiang prehistory were conducted, consequently diverging opinions among scholars on its main aspects quickly emerged. For instance, there have been different views on the chronological division of prehistory in Xinjiang: while some experts believe in the existence of a Bronze Age and an Iron $\mathrm{Age}^{2}$, others only conceive the idea of an early and a later period ${ }^{3}$, and others do not accept the existence of the Iron Age and insist that most of the remains belonged to the Bronze Age $\mathrm{A}^{4}$. Further disagreements have occurred over the grouping of major sites, and, although their chronology and cultural context of many remain often uncertain, relevant progress in the research on prehistory in Xinjiang are represented by the studies of Debain-Francfort ${ }^{5}$,

2. See G. Chen, "Several problems on the very ancient cultures in Xinjiang," Xinjiang Wenwu, no. 1 (1985): 27-38; G. Chen, "New ideas on the Neolithic cultures in Xinjiang", Kaogu, no. 4 (1987): 343-351; G. Chen, "On the Bronze Age and Early Iron Age cultures of Xinjiang," Kaogu, no. 4 (1990): 366-374; G. Chen, "Prehistoric cultures in Xinjiang", Xibei Minzu Yanjiu, no. 2 (1994): 101-111; G. Chen, "Discussion on Xinjiang Archaeology", Tulufan xue Yanjiu, no. 1 (2002): 16-30; J. Mei, Copper and Bronze Metallurgy in Late Prehistoric Xinjiang: Its Cultural Context and Relationship with Neighboring Regions (Oxford: Archaeopress, 2000).

3. See B. H. Wang, "A preliminary analysis of the archaeological cultures of the Bronze Age in the region of Xinjiang", Xinjiang shehui kexue, no. 4 (1985): 50-61; K. Chen, and T. H. Hiebert, "The Late prehistory of Xinjiang in relation to its neighbors," The Journal of World Prehistory 9, no. 2 (1995): 243-300.

4. T. Shui, "A comparative study of the Bronze Age cultures in Xinjiang", Guoxue Yanjiu, no. 1 (1993): 489.

5. C. Debain-Francfort, "Archéologie du Xijiang des origines aux Han" Primere partie ["Archaeology of Xinjiang from the origin to the Han dynasty" First part], Paléorient 14, no. 1 (1988): 5-29; C. Debain-Francfort, "Archéologie du Xijiang des origines aux Han" 
Chen \& Hiebert ${ }^{6} \mathrm{Mei}^{7}, \mathrm{Chen}^{8}$ and $\mathrm{Han}^{9}$. Their works propose five major temporal-cultural frameworks (Tables 1,2), which are reviewed in this paper in association with the excavation report of each site, if present.

Table 2. Frameworks Proposed by Scholars for Cultural Groups in the Iron Age

\begin{tabular}{|c|c|c|c|c|c|}
\hline & & & \multirow{3}{*}{ MEI JIANJUN } & \multirow{3}{*}{\begin{tabular}{|l|} 
CHENG GE \\
Qiemu'erqieke
\end{tabular}} & \multirow{3}{*}{$\begin{array}{l}\text { HAN JIANYE } \\
\text { Qiemu'erqieke II }\end{array}$} \\
\hline & FRANCFORT & CHEN-HIEBERT & & & \\
\hline $\begin{array}{l}\text { ALTAY } \\
\text { MOUNTAINS }\end{array}$ & $\begin{array}{l}\text { Qiemu'erqieke } \quad \text { (Fuyun } \\
\text { Kaketuohai }- \text { Tu'erhong } \\
\text { Qinghe - Habehe - Jiemunai } \\
\text { Bu'erjin - A'erkate) }\end{array}$ & & & & \\
\hline $\begin{array}{l}\text { YILI } \\
\text { VALLEY } \\
\text {-TACHENG } \\
\text { REGION }\end{array}$ & $\begin{array}{l}\text { Saka (Gongnaisi - Gongliu) } \\
\text { Mound tombs culture (Xiatai - } \\
\text { Zhongyangchang - Heishantou - } \\
\text { Yimuchang - Dacaotan) }\end{array}$ & $\begin{array}{l}\text { Saka (Xiangbaobao - Heishanxi } \\
\text { Tiemulike - Zhongyangahang } \\
\text { Yimuchang - Tieliegaishan } \\
\text { Nula sai - Yuantoushan } \\
\text { Dacaotan) }\end{array}$ & $\begin{array}{l}\text { Tiemulike (Sudunbulake } \\
\text { Zhongyanchang - Nulasai } \\
\text { Yimuchang - Heishantou) } \\
\text { Xiatai }\end{array}$ & $\begin{array}{l}\text {-Yili river and Pamir highlands } \\
\text {-culture (Tiemulike - Xiatai } \\
\text { Bom a - Y i muchan } \\
\text { Zhongyangchang- Anjihai } \\
\text { Heishantou-Ala - A fubai } \\
\text { Suodunbulake-Xiangbaobao) }\end{array}$ & $\begin{array}{l}\text { ds } \\
\text {-Qitai Dashitou; Suodunbulake } \\
\text {-M32; Qi'erzahai M7 }\end{array}$ \\
\hline \begin{tabular}{|l|} 
NORTHERN \\
TIANSHAN \\
MOUNTAINS \\
TURFAN- \\
BARKOL \\
\end{tabular} & & $\begin{array}{l}\text { Sidaogou } \quad \text { (Banji iegou } \\
\text { Hungqijijiecheng - Asitana } \\
\text { Sh hirenzi - Ke er rs ang } \\
\text { Lanzhouwanzi-Kuisu) }\end{array}$ & $\begin{array}{l}\text { Alagou I (Dongfengchang) } \\
\text { Alagou II } \\
\text { Dalongkou (Dacaotan) } \\
\end{array}$ & $\begin{array}{l}\text { Subeixi (Yanghai - Sangeqiao - } \\
\text { Aidinghu - Jiaohe - Guoxi - } \\
\text { Alagou - Chaiwupu - Wulapo }\end{array}$ & $\begin{array}{l}\text { H a la he zh ou; Ya n g h a i; } \\
\text { Yinyayilake; Mulei nanqu; } \\
\text {-Dalongkou M5; Chaiwupu; } \\
\text {-Aidinghu M20; Yanghai cim } 2 \\
\text {-M239; Subeixi; Asitana; Wulapo; } \\
\text { - }\end{array}$ \\
\hline \multirow{2}{*}{$\begin{array}{l}\text { SOUTHERN } \\
\text { TIANSHAN } \\
\text { MOUNTAINS }\end{array}$} & \multirow{2}{*}{ Chawuhugou (Qunbake) } & $\begin{array}{l}\text { Chawuhugou (Alagou-Narenke - } \\
\text { Halamodun) }\end{array}$ & Chawuhugou & Nanshan) & \multirow{2}{*}{$\begin{array}{l}\text { Chawuhugou; Hanbuqihan; } \\
\text { Xintala T3-4; Baleqi'er M206; } \\
\text { Kemu'ertu'er M27; Mazafutang; } \\
\text { - Haladun; Akerekechengbo; } \\
\text { - Karega'y yi M15; Qunbake; } \\
\text {-Shanghuxiang M3 }\end{array}$} \\
\hline & & Qunbake & Baozidong & $\begin{array}{l}\text { Chawuhugou (Quanbake } \\
\text { Baozidong - A A buqihan } \\
\text { Zagunyuke - Ya'erhugoubei } \\
\text { Yinyayilake - Kageqiake) }\end{array}$ & \\
\hline $\begin{array}{l}\text { EAST } \\
\text { XINJAANG }\end{array}$ & & & $\begin{array}{l}\text { Hanqigou } \\
\text { Miao'ergou }\end{array}$ & $\begin{array}{l}\text { Yanbulake (Miao'ergou - } \\
\text { Wubaoshuikun - Laboqiaoke } \\
\text { Wupu - Hanaigou) }\end{array}$ & $\begin{array}{l}\text { Lafuqiaoke; Yanbulake; Wupu } \\
\text { M151; Aisikexia'er M1 }\end{array}$ \\
\hline \multicolumn{6}{|l|}{$\begin{array}{l}\text { EASTERN } \\
\text { TARIM } \\
\text { BASIN } \\
\end{array}$} \\
\hline $\begin{array}{l}\text { PAMIRS } \\
\text { HIGHLANDS }\end{array}$ & Xiangbaobao & Saka (see above) & Xiangbaobao & $\begin{array}{l}\text { Yili river and Pamir highlands } \\
\text { culture (see above) }\end{array}$ & $\begin{array}{l}\text { Xiangbaobao M10 } \\
\text { Xiabandi cim 2 M18 } \\
\text { is Wenguluoke } \\
\text { Kunluketala } \\
\text { Dewoleke } \\
\text { Aketala } \\
\end{array}$ \\
\hline \begin{tabular}{|l|} 
NORTHERN \\
KUNLUN \\
MOUNTAINS
\end{tabular} & Shanpula & & Zahongluke (kerya?) & $\begin{array}{l}\text { Shanpula } \\
\text { Zahongluke (Juwei) }\end{array}$ & \\
\hline
\end{tabular}

Source: Author.

Some more recently published discoveries are also briefly analysed in the hope of providing a new perspective to the understanding of early cultures in Xinjiang.

IIéme partie ["Archaeology of Xinjiang from the origin to the Han dynasty" Second part], Paléorient 15, no. 1 (1989): 183-213.

6. Chen, and Hiebert, "The Late prehistory of Xinjiang in relation to its neighbors", (1995): 243-300.

7. Mei, Copper and Bronze Metallurgy in Late Prehistoric Xinjiang: Its Cultural Context and Relationship with Neighboring Regions, 2000.

8. Chen Ge conducted several researches on the topic, and although the most recent one, G. Chen, "Discussion on Xinjiang Archaeology," Tulufan xue Yanjiu, no. 1 (2002): 1630 , is taken in higher consideration, the others have been also used in this paper.

9. J. Han, "Traditions and chronological frameworks of the Bronze Age and early Iron Age cultures in Xinjiang," Xinjiang Wenwu, no. 3 (2005): 57-99. 


\section{Bronze Age and Iron Age Cultures in Xinjiang}

In recent years, several frameworks for regional cultural distribution were proposed, and in most of them the remains are organized in roughly horizontal zones ${ }^{10}$.

A different perspective for identifying patterns of spatial distribution of ancient cultures is provided by the "ecological approach" of Chen \& Hiebert $^{11}$, which focuses on areas sharing ecological features. Considering its peculiar environment of harsh deserts surrounded by formidable mountains, Xinjiang was unlikely to be entirely suitable for human life. Large areas should have been uninhabited, while others, like the highlands and the desert basins oasis, were exploited for their environmental features. Sites located in the same ecological area shared the habitat as well as the materials. Since prehistoric evidence reflects the process of integration of human and environmental behaviours ${ }^{12}$, the "ecological approach" identifies common backgrounds for remains in the same ecological environment and, by contrast, emphasises local variants. Although this approach deserves to be further studied, it falls outside the scope of this paper. Thus, for convenience of discussion, here prehistoric remains are organized into 8 regions: Altay, northern slope and central valleys of the Tianshan mountains, Yili river valley and Tacheng region, southern slope of Tianshan mountains, eastern Xinjiang, eastern Tarim basin, Pamirs highlands and northern Kunlun (Figures 1, 2).

10. See T. Shui, "A comparative study of the Bronze Age cultures in Xinjiang", Guoxue Yanjiu, no. 1 (1993): 447-490; J. Mei, Copper and Bronze Metallurgy in Late Prehistoric Xinjiang: Its Cultural Context and Relationship with Neighboring Regions (Oxford: Archaeopress, 2000); Z. An," Cultural complexes of the Bronze Age in the Tarim Basin and surroundings areas," in The Bronze Age and Early Iron Age Peoples of Eastern Central Asia vol. 1, ed. V. Mair (Washington DC: Institute for the Study of Man, 1998), 4562.

11. K. Chen, and T. H. Hiebert, "The Late prehistory of Xinjiang in relation to its neighbors", The Journal of World Prehistory 9, no. 2 (1995): 245-249.

12. The role of the environment as an active player in shaping ancient societies is analyzed in W. E. Boyd, and N. Chang, "Integrating social and environmental change in prehistory: a discussion of the role of landscape as a heuristic in defining prehistoric possibilities in NE Thailand," in Terra Australis: Altered ecologies - fire, climate and human influence on terrestrial landscapes, ed. S. Haberle, J. Stevenson and M. Prebble (Canberra: ANUE Press, 2010), 273-297. 


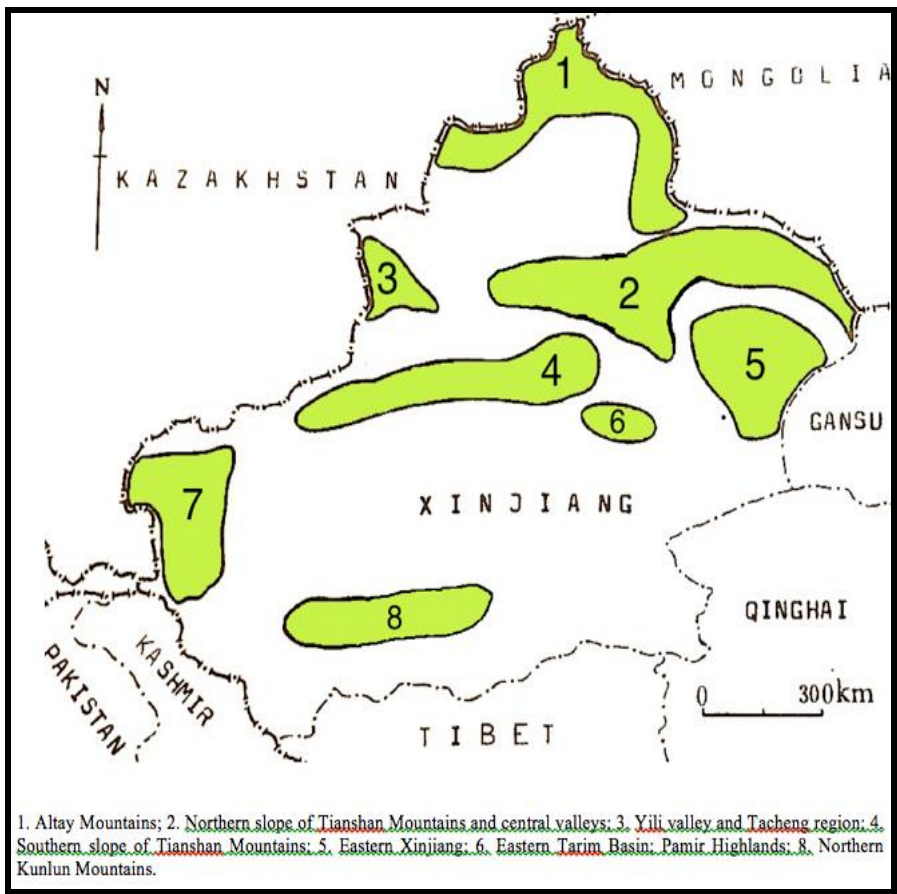

Figure 1. Geographical Distribution of Early Cultures in Xinjiang

Source: Adapted from Z. An, "Cultural complexes of the Bronze Age in the Tarim Basin and surroundings areas," in The Bronze Age and Early Iron Age Peoples of Eastern Central Asia, vol. 1, ed. V. Mair, (Washington DC: Institute for the Study of Man, 1998), 46, fig. 1.

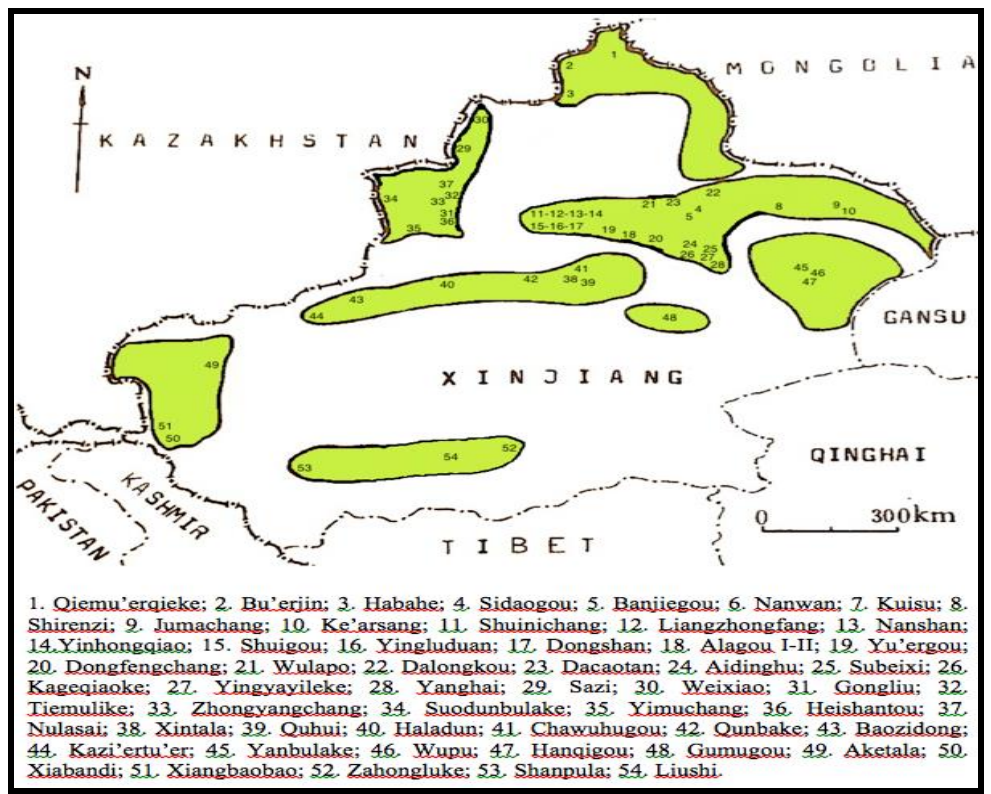

Figure 2. Map of the Sites Considered in this Paper

Source: Adapted from Z. An, "Cultural complexes of the Bronze Age in the Tarim Basin and surroundings areas," in The Bronze Age and Early Iron Age Peoples of Eastern Central Asia, vol. 1, ed. V. Mair (Washington DC: Institute for the Study of Man, 1998), 46, fig.1. 
Qiemu'erqieke site, on the western slope of the Altay mountains, has been assigned to the Bronze Age ${ }^{13}$ or to the Iron Age ${ }^{14}$. According to the preliminary report ${ }^{15}$, however, it is clear that the site presents different phases. More specifically, in the opinion of by Jia and Betts ${ }^{16}$, the site represents two periods: the earlier, Qiemu'erqieke I, was characterized by peculiar vessels, resembling those of the Afanasevo and Okunevo cultures, few pieces of bronze and casting moulds (Figure 3$)^{17}$; the later phase, Qiemu'erqieke II, is very little known and presented high-necked vessels and some iron items. According to this information, remains of Qiemu'erqieke I should be assigned to the Bronze Age, while the later stage might have belonged to the Iron Age. On the basis of the discovery of Qiemu'erqieke-type stele in diverse funerary contexts, some scholars hypothesized a wider distribution of "Qiemu'erqieke culture" ${ }^{18}$. However, although some similarities with remains in Bu'erjin and Habahe occur, the insufficient information on the later phase, the lack of carbon-dating and anthropological examinations of Qiemu'erqieke contexts do not allow a secure geographical distribution of the culture. To this respect, the work currently in press by professor Kovalev dedicated to Qiemu'erqieke site will help to clarify some of the aspects of the cemetery and the culture ${ }^{19}$.

13. K. Chen, and T. H. Hiebert, "The Late prehistory of Xinjiang in relation to its neighbors," 243-300; J. Mei, Copper and Bronze Metallurgy in Late Prehistoric Xinjiang. Its Cultural Context and Relationship with Neighboring Regions.

14. C. Debain-Francfort, "Archéologie du Xijiang des origines aux Han" Iléme partie, 183-213; G. Chen, "Discussion on Xinjiang Archaeology", 16-30.

15. Xinjiang Wenwu Kaogu Yanjiusuo, "Summary of excavation at Qiemu'erqieke cemetery," Wenwu, no. 1 (1981): 23-32.

16. P. Jia and A. Betts, "A re-analysis of the Qiemu'erqieke (Shamirshak) cemeteries, Xinjiang, China," The Journal of Indo-European Studies 38, no 3 \& 4 (2010): 275-317.

17. In the previous studies some bronze objects, including a knife and some arrowheads were assigned to the Bronze Age, however, when I was in Saint Petersburg Prof. Kovalev told me that only metal plaques, used to fix vessels can be attributed to the earlier in the stage of Qiemu'erqieke. A complete study on Qiemu'erqieke context, including this information will be soon published by him.

18. B. Wang, Study of grassland stone stele on the Silk Road (Urumqi: Xinjiang People's Press 1995).

19. A. Kovalev, Earliest European in the heart of Asia: the Chemurchek cultural phenomen vol. 1 (Saint Petersburg: Book Antiqua, 2014); A. Kovalev, Earliest European in the heart of Asia: the Chemurchek cultural phenomen vol. 2 (Saint Petersburg: Book Antiqua, 2015). 


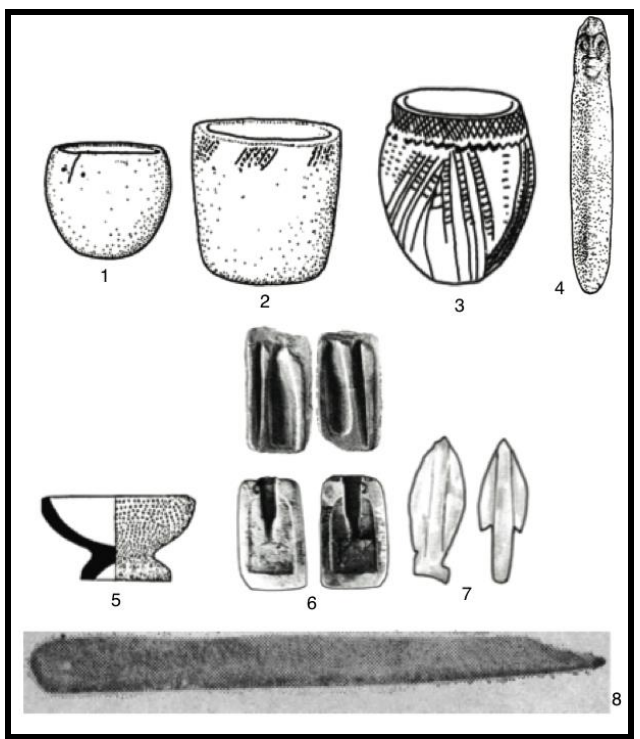

Figure 3. Grave goods from Qiemu'erqieke I: Stone Items $(1,2,4)$ and Casting Moulds (6), Pottery Vessels (3,5), Copper Implements (7,8).

Source: Figs. 1-7: P. Jia and A. Betts, "A re-analysis of the Qiemu'erqieke (Shamirshak) cemeteries, Xinjiang, China," The Journal of Indo-European Studies 38, nos. 3 , 4 (2010): 296, fig. 7; fig. 8: Xinjiang Wenwu Kaogu Yanjiusuo, "Summary of excavation at Qiemu'erqieke cemetery", Wenwu, no. 1 (1981): 27, fig. 8.

On the northern slope and in the valleys in the middle Tianshan range numerous sites have been unearthed, suggesting a long period of occupation of the area, from the Neolithic to historical times. Specifically, the currently available material shows that the valleys in the middle Tianshan Mountains were intensively inhabited during both the Bronze and Iron Ages, while on the northern slope the later period is poorly represented.

The Sidaogou site included houses and graves, representing two phases. Remains in T3-T5, dated by $\mathrm{C} 14$ to $1036-896^{20}$, included pottery painted with triangles and net-like designs, few copper items and fragments of clay casting moulds $^{21}$ (Figure 4.1, 2). Graves of the later phase, in T1-T2, were attributed by $\mathrm{C} 14$ to $700-300 \mathrm{BCE}^{22}$ and contained painted pottery, some copper implements and decorations. Although there are diverging opinions on the assignment of the Sidaogou site to the Iron $\mathrm{Age}^{23}$ or the Bronze $\mathrm{Ag}^{24}$, the latter attribution seems to be confirmed by the findings. Interestingly,

20. Shehui Xueyuan Kaogu Yanjiusuo, C14 Radiocarbon dates in Chinese archaeology (1965-1991) (Beijing: Wenwu chubanshe, 1991).

21. Xinjiang Weiyu'er Zizhiqu Wenhuating Wenwuchu, "The Sidaogou site in Mulei county Xinjiang", Kaogu, no. 2 (1982): 113-120.

22. Shehui Xueyuan Kaogu Yanjiusuo, C14 Radiocarbon dates in Chinese archaeology (1965-1991) (Beijing: Wenwu chubanshe, 1991).

23. K. Chen, and T. H. Hiebert, "The Late prehistory of Xinjiang in relation to its neighbors", 272-274; J. Han, "Traditions and chronological frameworks of the Bronze Age and early Iron Age cultures in Xinjiang," 57-99.

24. C. Debain-Francfort, "Archéologie du Xijiang des origines aux Han" Primere partie, 25 . 
$\mathrm{Mei}^{25}$ and $\mathrm{Han}^{26}$ hypothesized that the Sidaogou cemetery might have been in use during the Bronze Age and the Iron Age: actually, considering the C14-dating, this seems reasonable, nevertheless, given the total absence of bronze and iron in the context, further research is necessary to provide a reliable foundation for this hypothesis.

The Banjiegou site, severely damaged before the excavation, consisted in a settlement and several graves. The few recovered findings were stone implements and pottery fragments, one third of which was painted in black on a red slip with triangles and net-like designs (Figure 4.3). No metal was found $^{27}$. The site has been ascribed to the same cultural context as Sidaogou by most scholars because of the similarities of the pottery designs. Considering this and the geographical position of the two sites, it seems possible that Banjiegou could have been part of the "Sidaogou culture".

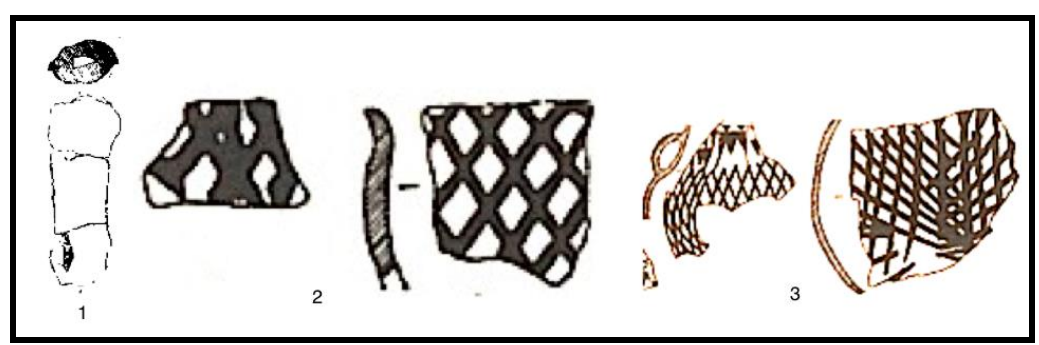

Figure 4. Pottery Casting Mould (1) and Painted Pottery (2) from Sidaogou and Painted Pottery from Banjiangou (3).

Source: Figs. 1, 2: Xinjiang Weiyu'er Zizhiqu Wenhuating Wenwuchu, "The Sidaogou site in Mulei county Xinjiang," Kaogu, no. 2 (1982): 166, figs. 7-8; fig. 3: G. Chen, "The Neolithic site at Banjiegou, Qitai county, Xinjiang," Kaogu, no. 6 (1981): 533, fig. 3.

The Nanwan cemetery included more than 100 graves. However, only M66 and M95 have been briefly published ${ }^{28}$. According to the descriptions, Nanwan burials were shaft-pits with wooden coffins, while the grave goods consisted of unpainted pottery vessels, few jars painted in black on a red slip, and some copper and bronze items. In M66 only two copper ornaments were found, while M95 was richer in metals, including copper and bronze implements and ornaments (Figure 5). Judging from the available material, the cemetery can be assigned to the Bronze Age.

The majority of scholars attributed diverse adjacent sites, such as Kuisu, Shirenzi, Junmachang and Ke'arsang, to the "Nanwan culture". However, the reports related to these remains are either brief or absent and,

25. J. Mei, Copper and Bronze Metallurgy in Late Prehistoric Xinjiang: Its Cultural Context and Relationship with Neighboring Regions, 13.

26. J. Han, "Traditions and chronological frameworks of the Bronze Age and early Iron Age cultures in Xinjiang," 57-99.

27. G. Chen, "The Neolithic site at Banjiegou, Qitai county, Xinjiang." Kaogu, no. 6 (1981): 552-553.

28. X. Chang, "Brief report on the excavation of $\mathrm{n} .66$ grave at the Nanwan cemetery in Balikun county," Xinjiang Wenwu, no. 1 (1985): 4-16; X. He, "The n. 95 grave at Nanwan, Balikun county, Xinjiang," Каоgи уи Wenwu, no. 5 (1987): 6-8. 
given the scarcity of information, it is difficult to propose a cultural affiliation.

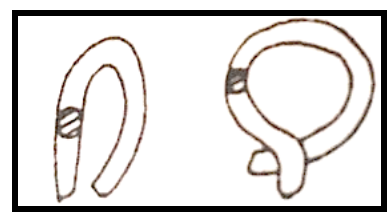

Figure 5. Earrings from Nanwan M95

Source: X. He, "The n. 95 grave at Nanwan, Balikun county, Xinjiang," Kaogu yи Wenwu, no. 5 (1987): 7 , fig. 2 .

Various sites were discovered in the 1990s in Shihezi city, but only brief descriptions of cemeteries in Shuinichang, Liangzhongfang, Nanshan, Yinhongqiao, Shuigou, Yangluduan, Dongshan and two hoards in Hongoushan, Qingkuang are currently available.

Cemeteries at Shuinichang and Liangzhongfang were severely damaged, however, archaeologists could still recover unpainted pottery vessels decorated on the upper part, similar to those found in the Karasuk contexts $^{29}$ (Figure 6.1,2). Both cemeteries included a small number of copper objects $^{30}$ (Figure 6.3). No C14-dating is available for these sites, so archaeologists dated the cemeteries to 1000-700 BCE on the basis of the findings.

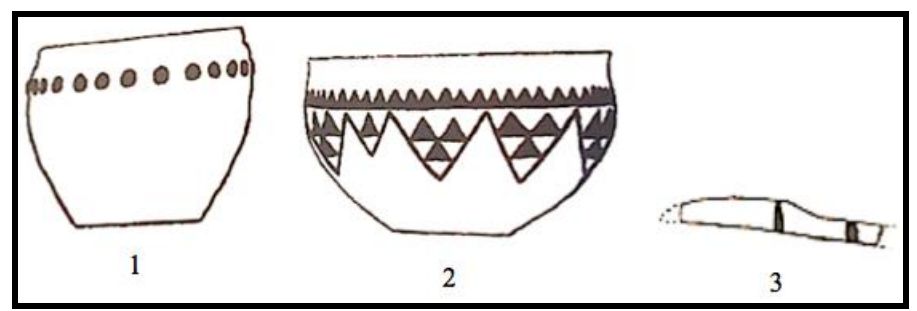

Figure 6. Pottery $(1,2)$ and a Bronze Knife (3) from Shuinichang Site

Source: Xinjiang Wenwu Kaogu Yanjiusuo, "Ancient tombs in Shihezi city," Xinjiang Wenwu, no. 4 (1994): 18, fig. 4.

Nanshan remains show peculiar burial rites, different from those of Shuinichang and Liangzhongfang: while in the latters the dead were placed on their side with bent legs, in Nanshan the posture was supine and extended. Pottery assemblage was distinct, consisting of painted handled pitchers and long-necked vessels. Bronze and iron knives and awls were also present in the Nanshan site (Figure 7). No C14-dating is available for this cemetery, which was dated by archaeologists to the Warring States period $(475-221 \mathrm{BCE})^{31}$. However, given the features of the assemblages, the date may be slightly earlier.

29. S. V. Kiselev, Ancient history of Southern Siberia (Moscow-Leningrad: Nauka, 1951), 159.

30. Xinjiang Wenwu Kaogu Yanjiusuo, "Brief report on the investigation at Shihezi city," Xinjiang Wenwu, no. 4 (1998): 54-64.

31. Xinjiang Wenwu Kaogu Yanjiusuo, "Ancient graves in Nanshan, Shihezi county, Xinjiang", Wenwu, no. 8 (1999): 46. 


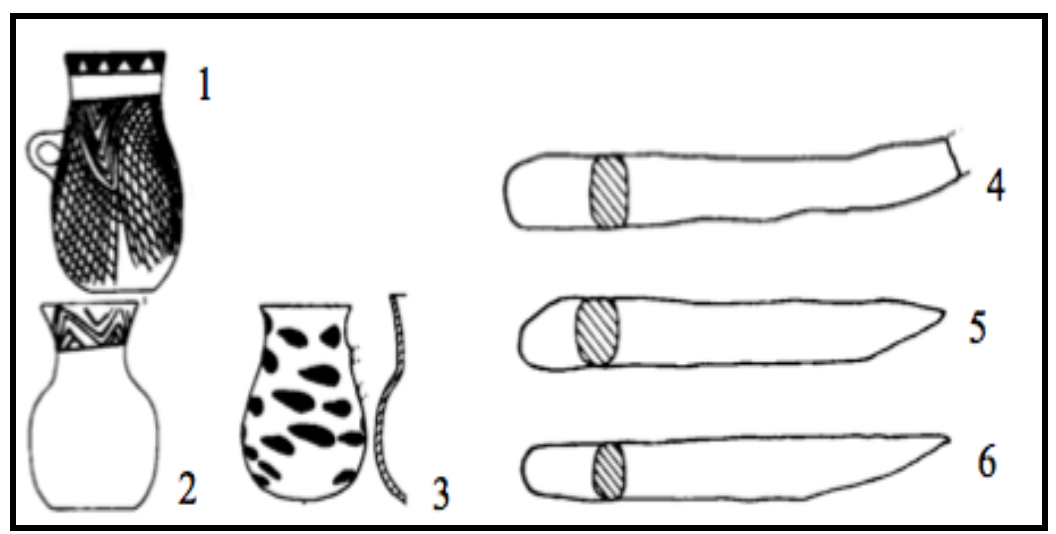

Figure 7. Remains at Nanshan Site: Painted Pottery $(1,2,3)$ and Iron Knives $(4,5,6)$.

Source: Xinjiang Wenwu Kaogu Yanjiusuo, "Ancient graves in Nanshan, Shihezi county, Xinjiang," Wenwu, no. 8 (1999): 42, fig. 8; 45, fig. 26.

Summarizing, in the hoards near Shehezi, numerous bronze implements and zoomorphic decorations, suggest an advanced state of metallurgy ${ }^{32}$, but since there are neither sufficient information nor dating available, it is difficult to place them within a specific context. The same can be said about the cemeteries in Yinhongqiao, Shuigou, Yangluduan, and Dongshan.

In the Shehezi area, the Shuinichang and Liangzhongfang cemeteries can be assigned to the Bronze Age $^{33}$, while Nanshan can be assimilated into a different cultural context and attributed to the Iron Age or slightly later. However, since very little information is available at present, it seems premature to establish any cultural attribution.

The Alagou site included two types of graves: the first type was a shaftpit tomb with a pebble-lined chamber, while the second was a shaft-pit grave lined with wooden slabs and covered by wooden logs. The two types were called Alagou I and II respectively ${ }^{34}$.

The grave goods in Alagou I included painted pottery vessels, bronze, iron and gold decorations, bone, agate and jade beads ${ }^{35}$ (Figure 8.1-3). Carbondating placed the site between the middle and the late first millennium ${ }^{36}$.

The settlement of Yu'ergou was assigned to the "Alagou I culture" by archaeologists on the basis of similar quality, colour and decorations of pottery $^{37}$, but, since the shape of many vessels is slightly different and no metal objects were found in Yu'ergou, this attribution is questionable (Figure 8).

32. Xinjiang Wenwu Kaogu Yanjiusuo "General report on the investigation at Shihezi city," Xinjiang Wenwu, no. 4 (1998): 54-64.

33. J. Mei, Copper and Bronze Metallurgy in Late Prehistoric Xinjiang: Its Cultural Context and Relationship with Neighboring Regions, 13.

34. Ibid., 17-18.

35. Xinjiang Wenwu Kaogu Yanjiusuo, "On the remains in Yu'ergou and the cemetery in Alagou, Urumqi," Kaogu, no. 4 (2014): 19-35.

36. Shehui Xueyuan Kaogu Yanjiusuo, C14 Radiocarbon dates in Chinese archaeology (1965-1991), 1991.

37. Xinjiang Wenwu Kaogu Yanjiusuo, "On the remains in Yu'ergou and the cemetery in Alagou, Urumqi," Kaogu, no. 4 (2014): 34. 
Debain-Francfort and Mei put the site of Dongfengchang ${ }^{38}$ within the Alagou I context because of the similarities in the burial practices and pottery items ${ }^{39}$, the latters consisting of fully-painted handled-pitchers and high-necked vessels (Figure 8.6-8). The small number of iron items found in the Dongfengchang site and its carbon-dating (1300-600 $\mathrm{BCE}^{40}$ ) support its affiliation with the "Alagou I culture", although it might have been slightly earlier than Alagou I site.

The Wulapo cemetery, near Urumqi, contained 46 graves. The assemblage included pottery vessels, copper and bronze implements and mirrors similar to the ones from the context of Alogou I (Figure 8.9-11). Iron items were also found and, as noted by $\mathrm{Mei}^{41}$, none of them is associated with painted pottery. Although no C14-dating is available for Wulapo, it was attributed to the Iron Age, more specifically dated to second half of the first millennium BCE, because of its similarities with Alagou I ${ }^{42}$.

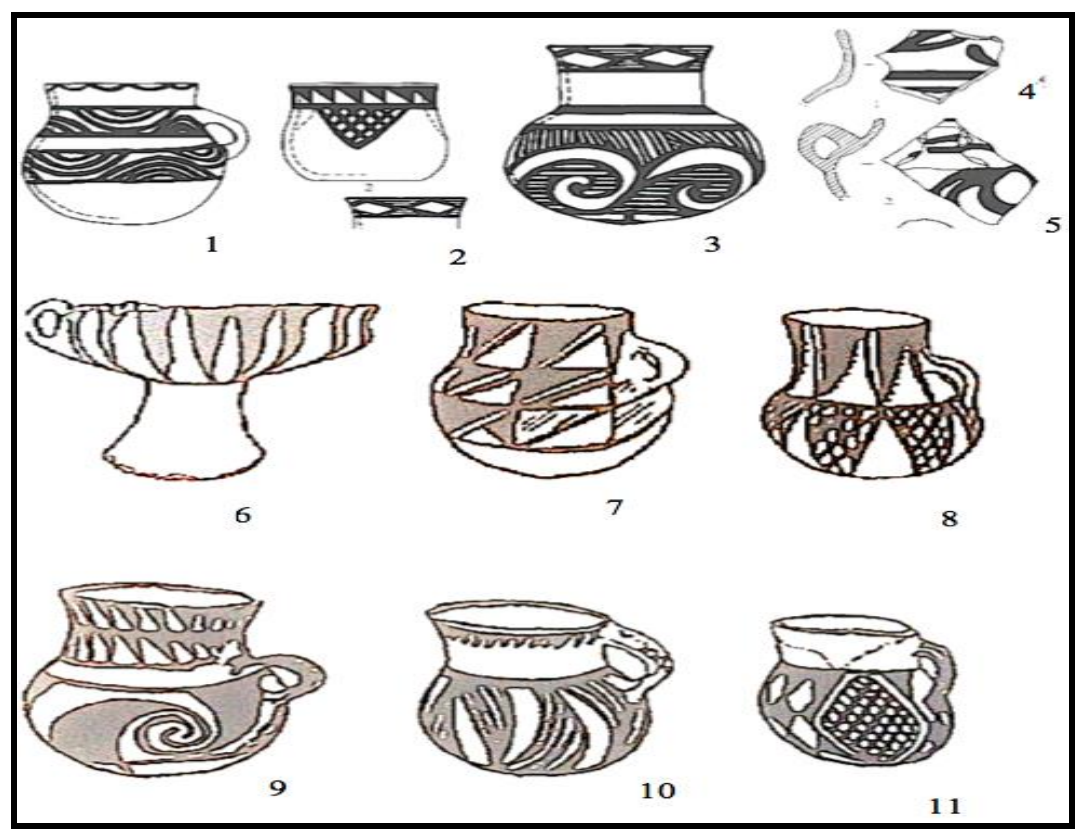

Figure 8. Painted Pottery from Alagou I (1-3), Yu'ergou (4,5). Pottery Vessels from Donfengchang (6-8) and Wulapo (9-11)

Source: Figs. 1-5: Xinjiang Wenwu Kaogu Yanjiusuo, "On the remains in Yu'ergou and the cemetery in Alagou, Urumqi", Kaogu, no. 4 (2014): 30, fig. 23; 24, fig. 11; figs. 6-11: C. Debain-Francfort, "Archéologie du Xijiang des origines aux Han" IIéme partie ["Archaeology of Xinjiang from the origin to the Han dynasty." Second part], Paléorient 15, no. 1 (1989): 195, fig. 16; 196, fig. 17.

38. Y. Zhang, "Archeological investigation and study of Alagou in the Tianshan mountains," Xibei Shidi, no. 3 (1987): 107-109.

39. C. Debain-Francfort, "Archéologie du Xijiang des origines aux Han" Iléme partie, 193-195; J. Mei, Copper and Bronze Metallurgy in Late Prehistoric Xinjiang: Its Cultural Context and Relationship with Neighboring Regions, 17-18.

40. Y. Zhang, "Archeological investigation and study of Alagou in the Tianshan mountians", 110-111.

41. J. Mei, Copper and Bronze Metallurgy in Late Prehistoric Xinjiang: Its Cultural Context andRelationship with Neighboring Regions, 19.

42. Ibid. 
Besides handmade unpainted pottery, the graves from Alagou II included large quantities of iron implements, and bronze, gold and silver zoomorphic decorations, whose style resembled that of the Saka culture. On this basis, Wang Binghua ${ }^{43}$ dated the site to the first millennium BCE. Lacquer items were also recovered, suggesting the existence of connections between Alagou II and the Central Plain cultures ${ }^{44}$.

Summarizing, the two Alagou types were both present in the Alagou valley almost simultaneously, however, the archaeological evidences suggest that they belonged to two different cultural groups.

At the moment, the most representative site for the Iron Age in the northern slope of the Tianshan range is the cemetery of Dalongkou, characterized by shaft-pit tombs marked on the surface by mounds and enclosures. The pottery assemblage consisted of handled jars and pitchers, few of which were painted. Metal objects included copper and bronze implements, one iron awl and a silver earring. Etched beads were also recovered in the graves, suggesting contacts with the Baozidong and Khotan and Indian contexts ${ }^{45}$ (Figure 9).

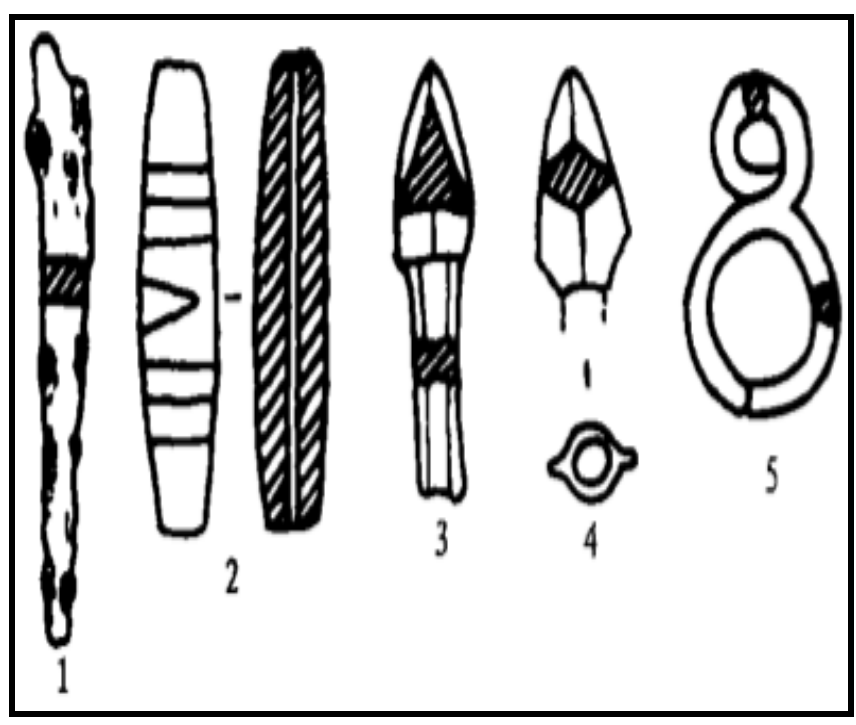

Figure 9. Iron (1), Bronze (3,4), Silver Items (5) and a Etched Bead (2) from Dalongkou Context

Source: Xinjiang Wenwu Kaogu Yanjiusuo, "Ancient cemetery in Dalongkou, Jemusa'er county," Kaogu, no. 9 (1997): 43, fig.8.

43. B. H. Wang, "A brief report of the excavation of burials with wooden chambers at Alagou, Xinjiang," Wenwu [Cultural Relics], no. 1, (1981): 22; B. H. Wang, "Recherches historiques prélimiaires sur les Saka du Xinjiang ancient" ["Preliminary historical research on Saka people in ancient Xinjiang"], Arts Asiatiques, no. 42 (1987): 31-44.

44 J. Mei, Copper and Bronze Metallurgy in Late Prehistoric Xinjiang: Its Cultural Context and Relationship with Neighboring Regions, 18.

45 A. Stein, Innermost Asia: Detailed Report of Explorations in Central Asia, Kan-su and Eastern Iran (Oxford: Clarendon Press, 1928): 110; L. T. Yablosky, "The material culture of the Saka and historical reconstruction" in Nomads of the Eurasian Steppe in the Iron Age, ed. J. Davis-Kimball, V. A. Bashilov and L. T. Yablosky, (Berekly: Zinat Press, 1995), 218, fig. 50. 
Also located on the northern slope of the Tianshan Mountains, the cemetery of Daocaotan has not been fully reported yet. From the little information available, funerary goods were poor, consisting of fragments of pottery and four bronze arrowheads similar to those found at Dalongkou ${ }^{46}$. Thus, it has been suggested an affiliation with these remains ${ }^{47}$. Given the scarcity of archaeological evidence, further excavations should be conducted in order to have a clear picture of the Iron Age in this area.

In the Turfan Basin several sites were excavated, which, according to most scholars, share many significant cultural traits. Thus, they have been grouped into a single culture variously named as Aidinghu culture ${ }^{48}$, Gushi culture $^{49}$ or Subeixi culture ${ }^{50}$. Following the main stream, in this paper it will be referred to as "Aidinghu culture". Major sites belonging to this tradition are the cemeteries in Aidinghu, Subeixi, Kageqiake, Yingyayilake, and Yanghai $^{51}$. The Aidinghu cemetery consisted of simple shaft-pit tombs, some of which were damaged. Grave goods included peculiar pottery handled jars, pitchers and cups painted in black on a red slip with triangles or vertical strips with net-like pattern inside ${ }^{52}$. The same designs were found on vessels recovered at the cemeteries in Yanghai, Kageqiake and Yingyayilake $^{53}$. Metal objects, found in the cemeteries of Aidinghu, Subeixi and Yanghai ${ }^{54}$, consisted of copper, bronze and iron implements, copper plaques, decorated with zoomorphic images and flower-like gold ornaments. Similar decorations were found in Alagou II, suggesting the existence of contacts between populations of the Tianshan valleys and the Turfan Basin (Figures 10, 11).

46 Xinjiang Wenwu Kaogu Yanjiusuo, "The rock-fill tombs discovered at Dacaotan, Miquan, Xinjiang," Kaogu yи Wenwu, no. 1 (1986): 36-38.

47 J. Mei, Copper and Bronze Metallurgy in Late Prehistoric Xinjiang: Its Cultural Context and Relationship with Neighboring Regions, 22.

48 K. Chen, and T. H. Hiebert, "The Late prehistory of Xinjiang in relation to its neighbors," 264-265; J. Mei, Copper and Bronze Metallurgy in Late Prehistoric Xinjiang: Its Cultural Context and Relationship with Neighboring Regions, 20.

49 C. Debain-Francfort, "Archéologie du Xijiang des origines aux Han" IIéme partie, 189.

50 Chen Ge proposed to group the remains in the valleys and northern Tianshan mountains, Turfan basin and Barkol grassland into a single cultural group, named Subeixi culture. Since there are similarities among these remains, this hypothesis is interesting and needs to be object of further studies. See G. Chen, "Discussion on Xinjiang Archaeology," 16-30.

51 C. Debain-Francfort, "Archéologie du Xijiang des origines aux Han" Iléme partie, 189-197; J. Mei, Copper and Bronze Metallurgy in Late Prehistoric Xinjiang: Its Cultural Context and Relationship with Neighboring Regions, 19-20.

52 Y. Li and H. Liu, "Ancient cemetery at Aidinghu, Tulufan, Xinjiang," Kaogu, no. 4 (1982): 365-72.

53 Xinjiang Wenwu Kaogu Yanjiusuo, "New result of archeological survey in Yanghai cemetery, Shanshan county, Xinjiang," Kaogu, no. 5 (2002): 3-7; H. Liu and Y. Zhang, "Investigation of the Yiyayilake cemetery in Tuokexun county, Xinjiang," Kaogu, no. 7, (1985): 597-603; H. Liu, and Y. Zhang, "Ancient cemetery at Kageqiake, Tuokexun county, Xinjiang," Kaogu, no. 7 (1987): 597-603.

54 The cemeteries of Kageqiake and Yingyayilake were severely damaged and only several pottery vessels were found during the excavations. 


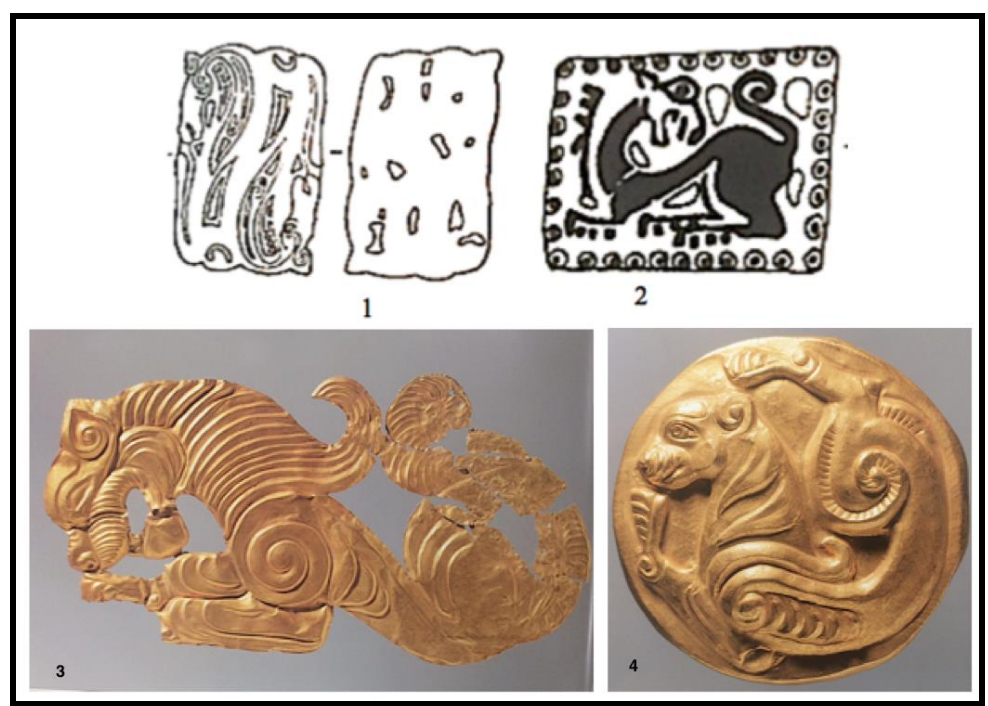

Figure 10. Zoomorphic Plaques from Aidinghu (1) after Y. Li \& H. Liu 1982: 369, fig. 7; Subeixi (2), and Alagou $(3,4)$

Source: Fig. 1: Y. Li and H. Liu, "Ancient cemetery at Aidinghu, Tulufan, Xinjiang", Kaogu, no. 4 (1982): 369, fig. 7; fig. 2: Tulufan Wenwusuo, "Burials in Subashen, Shanshan county, Xinjiang" Kaogu, no. 1 (1984): 46, fig. 8; figs. 3,4: Chinese Museum of History, Tianshan Gudao dongxifeng [East and West along the ancient Tianshan road] (Beijing: Zhongguo shehui chubanshe, 2002), 34, 38.

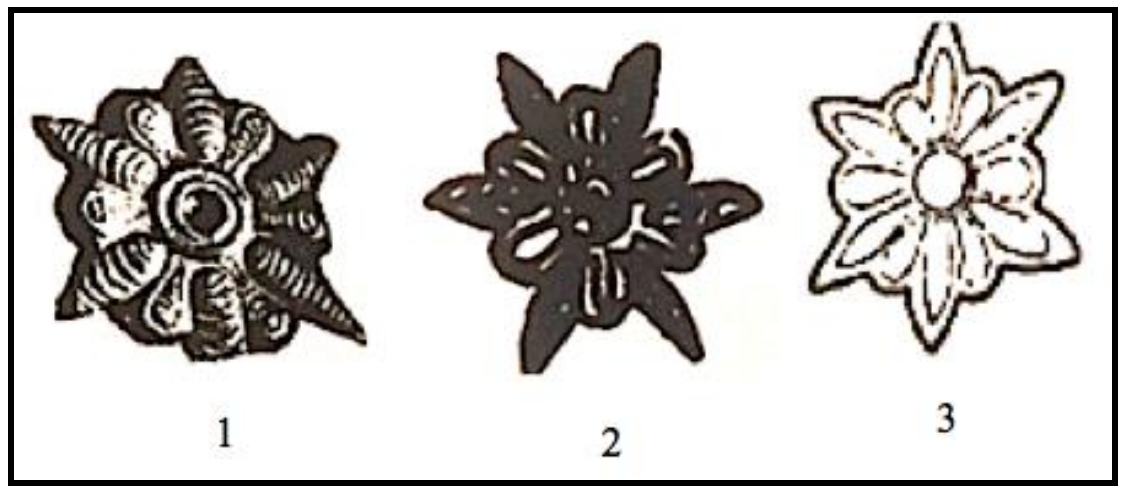

Figure 11. Flower-like Gold Ornaments. Aidinghu (1), Yanghai (2) and Alagou I (3)

Source: Fig. 1: Y. Li and H. Liu, "Ancient cemetery at Aidinghu,Tulufan, Xinjiang," Kaogu, no. 4 (1982): 369, fig. 7; fig. 2: Xinjiang Wenwu Kaogu Yanjiusuo, "Brief report of the examination of ancient cemetery at Yanghai," Xinjiang Wenwu, no. 4 (1989): 39, fig. 6; fig. 3: B. H. Wang, "A brief report of the excavation of burials with wooden chambers at Alagou, Xinjiang", Wenwu, no. 1 (1981): 20, fig. 6.

The Subeixi cemetery presents two phases, an early and a later one, represented by M8 and M3 respectively ${ }^{55}$ : in M8 no metal artefacts were found, while M3 was rich of bronze, iron, and lacquer objects. By contrast, pottery in the two phases was similar and unpainted. The long occupation of the Subeixi site was also suggested by carbon-dating, which dated the early

55 Tulufan Wenwusuo, "Burials in Subashen, Shanshan county, Xinjiang", Kaogu, no. 1 (1984): 41-51; Xinjiang Wenwu Kaogu Yanjiusuo, "Brief report of the excavation of the cemetery I at Subeixi, Shanshan county Xinjiang", 1-13. 
phase to $1422-1227 \mathrm{BCE}$ and the later to $360-110 \mathrm{BCE}^{56}$. So, the Subeixi cemetery can be ascribed to the Bronze and Iron Ages.

Although some differences can be noticed, especially in the pottery decoration, remains in the Turfan Basin present clear similarities. Moreover, C14-dating available for Subeixi, Aidinghu, Kageqiake and Yingyayilake ${ }^{57}$, allocated all of them within the range of the middle-late first millennium $\mathrm{BCE}^{58}$. Thus, the attribution of the sites to the same Iron Age cultural group finds support.

In the Yili River valley and Tacheng region, the Bronze Age is represented by three briefly reported sites, namely Sazi and Weixiao cemeteries and the hoard at Gongliu. Pottery items and metal artefacts from Yili-Tacheng area resembled those of the Andronovo culture (ca. 2000-900 $\mathrm{BCE}$ ) in Kazakhstan, suggesting close connections between the two areas ${ }^{59}$ (Figure 12).

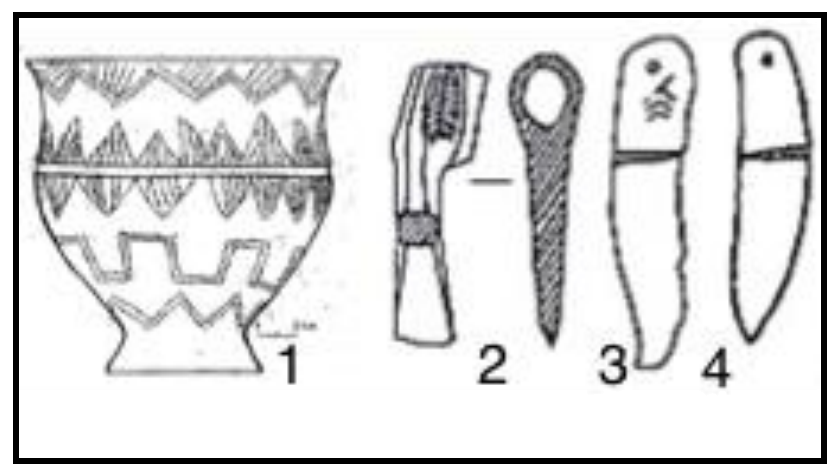

Figure 12: Andronovo-type Pottery (1) from Sazi Cemetery, Tuoli County and Bronze and Copper Objects from Gongliu Hoard (2-4)

Source: Fig. 1: J. Zhou and W. Li, "Ancient burials at Sazi village, Tuoli county," Xinjiang Wenwu, no. 2 (1996): 389, fig. 6; figs. 2-4: B. Wang, and Z. Cheng, "A group of bronze artifacts unearthed in Gongliu county," Xinjiang Wenwu, no. 8 (1989): 95, fig. 2.

Remains attributed to the Iron Age, such as those of Tiemulike ${ }^{60}$, Zhongyangchang $^{61}$ and Suodunbulake ${ }^{62}$, have been considered as representing one cultural group named "Tiemulike culture". These sites all included unpainted pottery vessels and bronze anthropomorphic artefacts, similar to those from the Saka contexts ${ }^{63}$ (Figure 13). C14-dating for

56. Shehui Xueyuan Kaogu Yanjiusuo, C14 Radiocarbon dates in Chinese archaeology (1965-1991).

57. Ibid.

58. As seen, the exception is of the early phase of Subeixi site.

59. J. Mei, Copper and Bronze Metallurgy in Late Prehistoric Xinjiang: Its Cultural Context and Relationship with Neighboring Regions, 14.

60. Xinjiang Wenwu Kaogu Yanjiusuo, "Tiemulike cemetery, Xinyuan, Xinjiang", 59-66; S. Li, "Typological study on the bronze objects found in Aga'ersen, Yili river valley," Bianjiang Kaogu Yanjiu, no. 2 (2014): 99-110.

61. Xinjiang Wenwu Kaogu Yanjiusuo, "Stone cist tomb at Zhongyangchang, Gongnaisi, Xinyuan, Xinjiang," Каogu уи Wenwu, no. 2 (1985): 21-6.

62. Xinjiang Wenwu Kaogu Yanjiusuo, "Ancient cemetery at Suodunbulake in Chabucha'er county", Xinjiang Wenwu, no. 2 (1995): 1-19.

63. C. Debain-Francfort, "Les Saka du Xinjiang avant le Hans (20av-220ap): critères 
Tiemulike and Suodunbulake cemeteries placed the remains into the range of 770-200 $\mathrm{BCE}^{64}$, which roughly corresponds to the period of the Saka occupation of the Yili River valley ${ }^{65}$. Thus, the "Tiemulike culture" might have been a local variant of the Saka's. The local character of the Tiemulike group is suggested by the discovery of the Nulasai copper mining and smelting centre, which offers evidence of local metallurgy. It was C14 dated to $900-400 \mathrm{BCE}^{66}$ and at present there is no evidence of an earlier exploitation. However, the site has not yet been fully excavated and its context is still fairly vague.

Other sites yielding iron objects were excavated in the Yili-Tacheng area, namely Yimuchang, Heishantou, but no reports have been published yet. The little information provided by the brief descriptions available suggests their assignment to the Iron Age ${ }^{67}$.

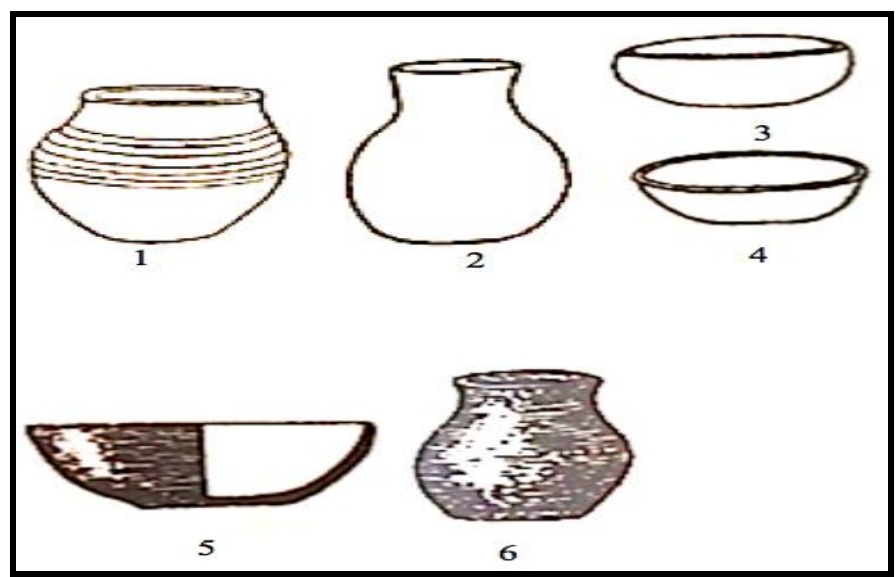

Figure 13: Pottery from Tiemulike Site (1-4) and Pottery of the Saka Culture $(5,6)$

Source: figs. 1-4: T. Shui, "A comparative study of the Bronze Age cultures in Xinjiang," Guoxue Yanjiu, no. 1 (1993): 473, fig. 12; figs. 5,6: M. G. Moshkova, Steppe zone of the Asiatic part of the URSS in the Scytho-Sarmatian time (Moscow: Hayka, 1992), 354, fig. 4.

Regarding the prehistory in the southern slope of Xinjiang most of the scholars agree that the Bronze Age is represented by the remains in Xintala,

d'indentification" ["Saka people in Xinjiang before the Han period: criteria of identification"], in Nomades et sédentaires en Asie centrale: apports de l'archéologie et de l'etnologie : actes du Colloque franco-soviétique Alma Ata (Kazahkstan) 17-26 octobre 1987, ed. Henri-Paul Francfort (Paris : Centre National de la Recherche Scientifique 1990), 81-95.

64. Shehui Xueyuan Kaogu Yanjiusuo, C14 Radiocarbon dates in Chinese archaeology (1965-1991).

65. J. Mei, Copper and Bronze Metallurgy in Late Prehistoric Xinjiang: Its Cultural Context and Relationship with Neighboring Regions, 21-22.

66. Shehui Xueyuan Kaogu Yanjiusuo, C14 Radiocarbon dates in Chinese archaeology (1965-1991), 1991.

67. X. Chang, "Investigation of the Neolithic site at Junmachang, Yiwu," Xinjiang Wenwu, no. 1 (1986): 14-15; G. Chen, "A preliminary research on early cultures in Xinjiang", Zhongya Xuekan, no. 4, (1995): 5-72; Y. Zhang, "The discovery and study of the tombs in the Yili valley", Xinjiang Wenwu, no. 3 (1989): 11-22. 
Quhui and Haladun, while the cemeteries of Chanwuhugou, Qunbake and Boazidong should be assigned to the Iron Age.

The Xintala remains present two phases, an earlier one (T3-4), where no metals were found, and a later stage (T1-2), in which evidence of early metallurgy is shown by some copper items, arrowheads, awls, and a bronze socketed axe of the Andronovo-type ${ }^{68}$ (Figure 14). Interestingly, Han placed the remains of Xintala within the Iron Age context, on the basis of the pottery characteristics ${ }^{69}$. The site of Quhui has been assigned to the late Xintala culture: although no metal was found there, this attribution is supported by similar painted pottery vessels.

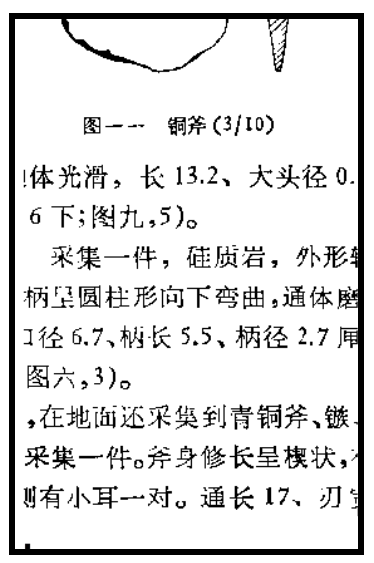

Figure 14. Bronze Socketed Axe from Xintala Site

Source: After Xinjiang Wenwu Kaogu Yanjiusuo, "Excavation of the Xintala site, Heshuo, Xinjiang", Kaogu, no. 5 (1988): 403, fig. 11.

In the Haladun site a fairly large assemblage of painted pottery and polished stone was found. The absence of metal items led some scholars to assign the settlement to the Neolithic period ${ }^{70}$. By contrast, others placed it within the late II millennium BCE, in the Bronze Age context, on the basis of the similarities of the stone objects (especially the crescent-shape knives) with those of the Chust culture (ca.1500 BCE) ${ }^{71}$.

The Chawuhugou site consisted of five cemeteries containing about 2000 graves ${ }^{72}$. The 600 burials excavated so far revealed distinctive funeral

68 Xinjiang Wenwu Kaogu Yanjiusuo, "Excavation of the Xintala site, Heshuo, Xinjiang", Kaogu, no. 5 (1988): 399-407.

69 J. Han, "Traditions and chronological frameworks of the Bronze Age and early Iron Age cultures in Xinjiang," Xinjiang Wenwu, no. 3 (2005): 57-99.

70. W. Huang, Report of the archaeological excavations in Xinjiang (1957-1958) (Beijing: Wenwu chubanshe, 1983).

71. K. Chen, and T. H. Hiebert, "The Late prehistory of Xinjiang in relation to its neighbors," 269.

72. Xinjiang Wenwu Kaogu Yanjiusuo, "Brief report of the excavation in 1986 of the cemetery IV at Chawuhugou, Hejing county Xinjiang," Xinjiang Wenwu, no. 1 (1987): 1-9; Xinjiang Wenwu Kaogu Yanjiusuo, "The excavation of the cemetery II at Chawuhugou, Hejing county, Xinjiang," Xinjiang Wenwu, no. 4 (1989): 12-33; Xinjiang Wenwu Kaogu Yanjiusuo [Xinjiang Institute of Archaeology], "Brief report of the excavation of the cemetery I at Chawuhugou, Hejing county Xinjiang", Xinjiang Wenwu, no. 4 (1992): 11-64; Xinjiang Wenwu Kaogu Yanjiusuo [Xinjiang Institute of Archaeology], "Brief report of the 
materials, suggesting that Chawuhugou site was a regional cultural centre. Cemeteries in Chawuhugou are rich of copper and bronze implements, weapons, mirrors and decorations, while iron knives, awls and rings were found only in cemeteries I, II and III (Figure 15). Cemeteries I and II were C14 dated to 1000-400 and 800-380 respectively, while two carbon-dating for cemeteries IV and V put them within the range of 753- $1 \mathrm{BCE}^{73}$.

Despite the relative internal chronology, the Chawuhugou context shows homogeneity with respect to the burial structures, which were shaft-pits marked on the surface with stone piles and/or enclosures, and to pottery, which was red and handmade. The most common vessels were spouted jugs with a single handle, handled cups and jars, painted in black or dark-red on a red slip. On this basis, the Chawuhugou cemeteries have been considered one cultural group, which, according to some scholars, included the Qunbake site ${ }^{74}$.

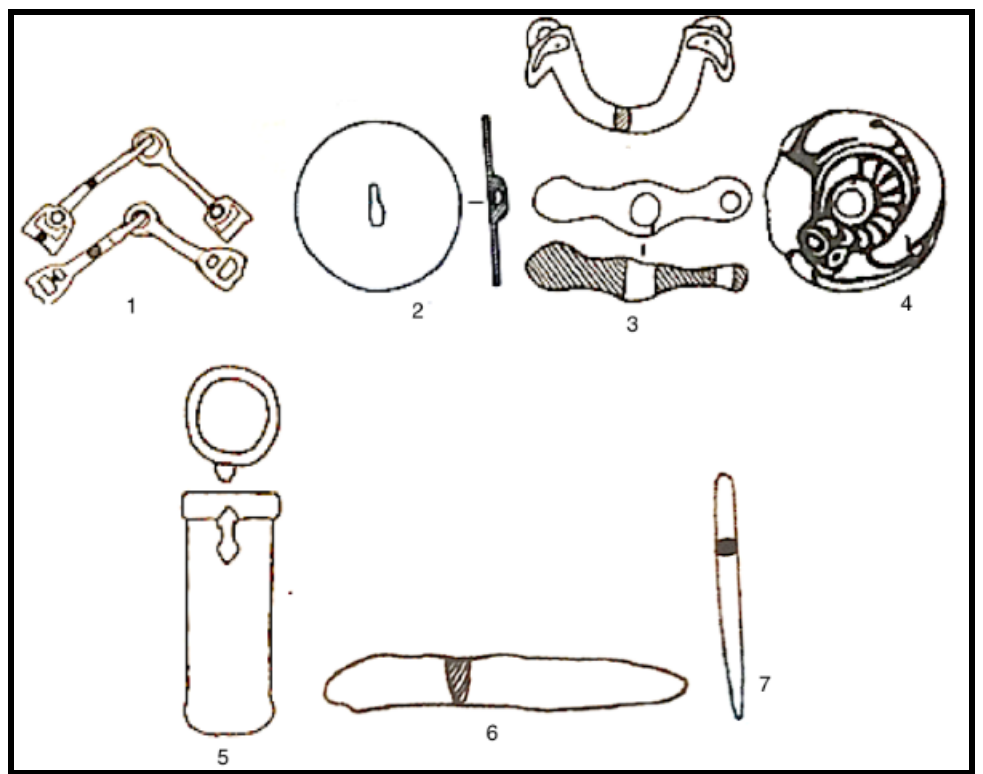

Figure 15. Metal Objects from the Chawuhugou Context: Copper and Bronze Items (1-5) and Iron Implements $(6,7)$

Source: Figs. 1,3,6: Xinjiang Wenwu Kaogu Yanjiusuo, "Brief report on the excavation in 1987 of the cemetery IV at Chawuhugou pass, Hejing county, Xinjiang", Xinjiang Wenwu, no. 4 (1988): 18; fig. 2, 7, 13, 14, 20: Xinjiang Wenwu Kaogu Yanjiusuo, "Brief report of the excavation of the cemetery I at Chawuhugou, Hejing county Xinjiang," Xinjiang Wenwu, no. 4 (1992): 54; fig. 4, 5, 40, 42, 59, after Xinjiang Wenwu Kaogu Yanjiusuo, "Brief report of the excavation in 1986 of the cemetery IV at Chawuhugou, Hejing county Xinjiang," Xinjiang Wenwu, no. 1 (1987): 6, fig. 6.

excavation of the cemetery V at Chawuhugou, Hejing county Xinjiang", Xinjiang Wenwu, no. 2 (1992): 15-30; Xinjiang Shehui Xueyuan Kaogu Yanjiusuo Xinjiangdui, "Report on the excavation of the cemetery II at Chawuhu pass, Hejing county Xinjiang", Kaogu, no. 6 (1990): 511-518.

73. Shehui Xueyuan Kaogu Yanjiusuo, C14 Radiocarbon dates in Chinese archaeology (1965-1991).

74. C. Debain-Francfort, "Archéologie du Xijiang des origines aux Han" IIéme partie, 183-213; G. Chen, "Western Region in prehistoric period" in Xiyu Tongshi [History of the Western Region], ed. T. Yu (Zhengzhou: Zhengzhou Guji Chubanshe 1996), 18. 
Three cemeteries discovered in Qunbake present indeed strong similarities with the Chawuhugou remains. Despite minor differences in the burial manners and in a small number of red-painted pottery vessels ${ }^{75}$, the assemblage of spouted jugs with single handle, cups and jars with one or two handles paralleled the ones in Chawuhugou. Regarding metal findings, the Qunbake cemeteries included copper, bronze and iron items ${ }^{76}$. Among them, implements and decorations resembled those of Chawuhugou, while copper handled mirrors were found only in Qunbake (Figure 16).

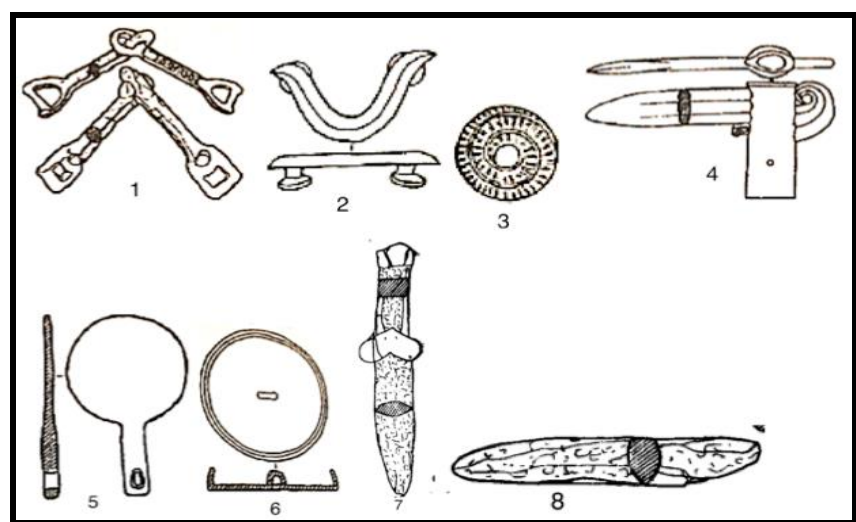

Figure 16. Copper and Bronze Items (1-6) and Iron Weapons $(7,8)$ from Qunbake Cemeteries

Source: Figs. 1-5, 7, 8: Xinjiang Shehui Xueyuan Kaogu Yanjiusuo Xinjiangdui, "A brief report of the second and third excavations of ancient tombs at Qunbake, Luntai, Xinjiang," Kaogu, no. 8 (1991): 701; fig. 14; fig. 6: Xinjiang Shehui Xueyuan Kaogu Yanjiusuo Xinjiangdui, "A preliminary report on the first excavation of ancient tombs at Qunbake, Luntai, Xinjiang," Kaogu, no. 11 (1987): 993, fig. 10.

The Baozidong site is located in the eastern part of Tianshan mountains, close to the Pamir highlands, thus the discovery of the items possessing characteristics of both the southern Tianshan region and the Saka culture in Kazakhstan (ca. mid-I millennium BCE) may not surprise: while the pottery vessels' style was close to that of Chawuhugou, the etched beads link the Baozidong cemetery to the Saka context ${ }^{77}$ (Figure 17). The mixed assemblage of Baozidong, which also included bronze, iron and gold, has generated disagreement over its cultural attribution: it was assigned to the Saka horizon or the Chust culture ${ }^{78}$, to the Chawuhugou culture ${ }^{79}$ and also considered as a separate cultural group ${ }^{80}$.

75. J. Mei, Copper and Bronze Metallurgy in Late Prehistoric Xinjiang: Its Cultural Context and Relationship with Neighboring Regions, 17.

76. Xinjiang Shehui Xueyuan Kaogu Yanjiusuo Xinjiangdui, "A brief report of the second and third excavations of ancient tombs at Qunbake, Luntai, Xinjiang," 684-703.

77. L. T. Yablosky, "The material culture of the Saka and historical reconstruction" in Nomads of the Eurasian Steppe in the Iron Age, 218, fig. 50.

78. T. Shui, "A comparative study of the Bronze Age cultures in Xinjiang," 474-476.

79. G. Chen, "Western Region in prehistoric period," 18.

80. J. Mei, Copper and Bronze Metallurgy in Late Prehistoric Xinjiang: Its Cultural Context and Relationship with Neighboring Regions, 15. 


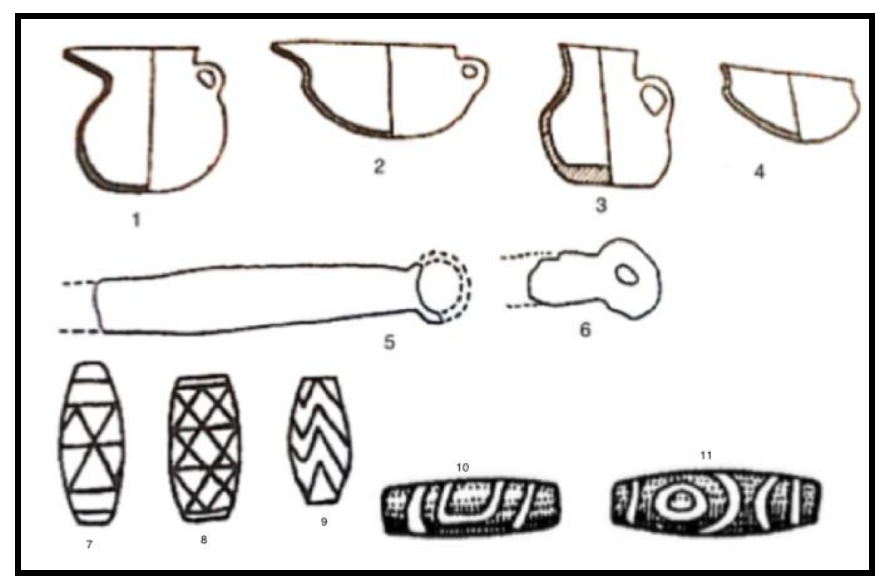

Figure 17. Grave Goods from Baozidong Cemetery: Pottery (1-4), Iron Knives (5,6) and Etched Beads (7-9). Beads from Saka Culture Contexts $(10,11)$

Source: Figs. 1-6: B. Wang and X. Chang, "The investigation and excavation of the ancient tombs at Baozidong, in Wensu county," Xinjiang Wenwu, no. 2 (1986): 5; fig. 8, 7, figs. 1012: L. T. Yablosky, "The material culture of the Saka and historical reconstruction," in Nomads of the Eurasian Steppe in the Iron Age, ed. J. Davis-Kimball, V. A. Bashilov and L. T. Yablosky (Berekly: Zinat Press, 1995), 218, fig. 50.

The cemetery of Kazi'ertu'er, presents strong similarities with the one at Baozidong, especially concerning pottery types and metal objects. By contrast, the large quantity of painted pottery in Kazi'ertu'er is distinctive ${ }^{81}$ (Figure 18). Since many findings have not been studied yet, at the moment it is premature to propose an affiliation with the Baozidong site.

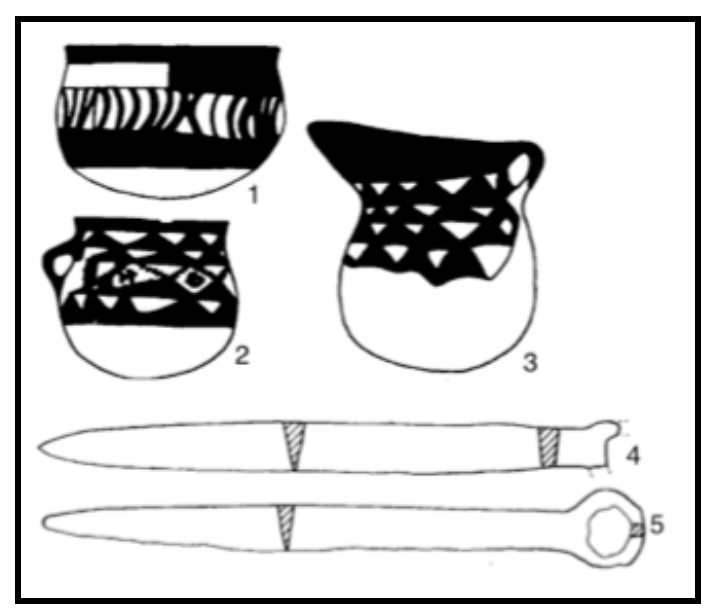

Figure 18. Grave Goods from Kazi'ertu'er Cemetery: Painted Pottery (1-3) and Copper Knives $(4,5)$

Source: Xinjiang Wenwu Kaogu Yanjiusuo, "Report of the first excavation in Kezi'ertu'er cemetery, Baicheng county, Xinjiang," Kaogu, no. 6 (2002): 21, fig. 15; 21, fig. 14; 24, fig. 17.

81. Xinjiang Wenwu Kaogu Yanjiusuo, "Report of the first excavation in Kezi'ertu'er cemetery, Baicheng county, Xinjiang," no. 6 (2002): 14-30. 
Located in the eastern part of Xinjiang, Yanbulake cemetery has been generally considered a distinctive cultural centre ${ }^{82}$, attributed to the Bronze $\mathrm{Age}^{83}$ or the Iron $\mathrm{Age}^{84}$. According to the burial practices and structures, the cemetery included at least three types of graves. From all of them large quantities of copper and bronze implements and ornaments were recovered, as well as painted and unpainted vessels, including handled pitchers, footed handled cups and long-necked jars, some of which resembled those found in Gansu $^{85}$. By contrast, a few iron items were found only in graves of the first type, suggesting the existence of two phases within the Yanbulake context (Figure 19). C14-dating to $1700-1000^{86}$ also indicates that the Yanbulake site was used for several hundreds years, allowing its assignment to the Bronze Age and the Iron Age.

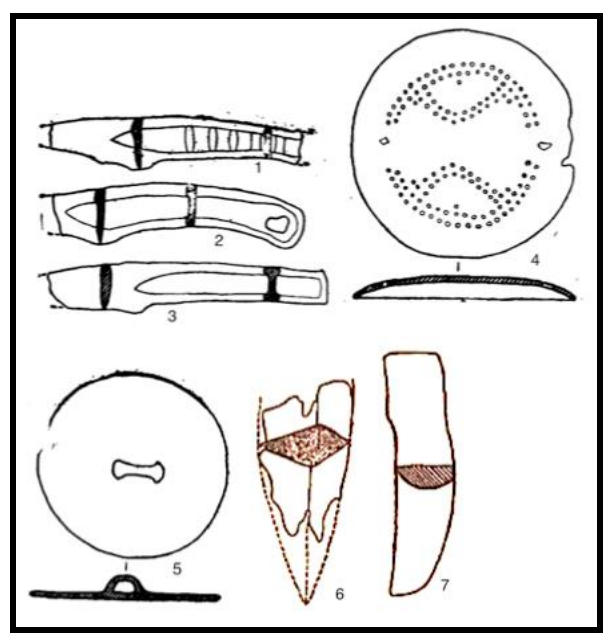

Figure 19. Remains from Yanbulake Cemeteries. Bronze Objects (1-5) and Iron Items $(6,7)$

Source: Xinjiang Weiyu'er Zizhiqu Wenhuating Wenwuchu, "The Yanbulake cemetery in Hami, Xinjiang," Kaogu Xuebao, no. 3 (1989): 344, fig. 23; 348, fig. 26.

For the Wupu cemetery only the report of two graves (M151, M152) is available. Wupu burials yielded handmade pottery jars, cups and longnecked vessels, few of which were painted in black on a red slip. Some

82. Z. An, "Cultural complexes of the Bronze Age in the Tarim Basin and surroundings areas," 47.

83. C. Debain-Francfort, "Archéologie du Xijiang des origines aux Han" IIéme partie, 183-213; K. Chen, and T. H. Hiebert, "The Late prehistory of Xinjiang in relation to its neighbors", 259-264; J. Mei, Copper and Bronze Metallurgy in Late Prehistoric Xinjiang: Its Cultural Context and Relationship with Neighboring Regions.

84. G. Chen, "On the Bronze Age and Early Iron Age cultures of Xinjiang", Kaogu, no. 4 (1990): 368; J. Han, "Traditions and chronological frameworks of the Bronze Age and early Iron Age cultures in Xinjiang," 57-99.

85. J. Mei, Copper and Bronze Metallurgy in Late Prehistoric Xinjiang: Its Cultural Context and Relationship with Neighboring Regions, 12; C. Thorthon and T. Shurr, "Genes, language and culture: an example from the Tarim basin," Oxford Journal of Archaeology, 23, no. 1 (2004): 88.

86. Shehui Xueyuan Kaogu Yanjiusuo, C14 Radiocarbon dates in Chinese archaeology (1965-1991). 
copper decorations were also recovered. C14-dating places it around 1100 $\mathrm{BCE}$, thus it can be assigned to the Bronze Age ${ }^{87}$.

The Hanqigou cemetery shows strong similarities with the Yanbulake site with respects to burial practices and pottery forms, but it yielded unpainted pottery and no iron items were found there. However, on the basis of one C14-dating ${ }^{88}$, Mei put the Hanqigou cemetery within the Iron Age context and speculated that it might have developed from the Yanbulake later phase ${ }^{89}$.

Two groups of graves in the Gumugou cemetery are located on the eastern rim of the Tarim basin. Here, early evidence of copper use is represented by two small copper fragments and traces of bronze cutting tools on wooden poles ${ }^{90}$. Gumugou site was $\mathrm{C} 14$-dated to $1800 \mathrm{BCE}^{91}$ and can be ascribed to the early Bronze Age. Gumugou type I and Qiemu'erqieke type I in Altay city share some cultural traits, especially concerning the burial structures and the typology of grave goods. Nevertheless, maybe because of the use of different materials, wood and stone respectively, scholars are reluctant to accept the connection between the two contexts. Attempts to link Gumugou to the northern regions were made by Han Kangxin, who found similarities between skulls from cemetery I and those from Afanasievo's graves, thus he speculated that Gumugou people were migrants from the highlands ${ }^{92}$.

Pamir highlands have been little investigated and only three major sites have been reported so far. Findings recovered on the surface of the Aketala site were initially assigned to the Neolithic or Chalcolithic, on the basis of the high number of stone implements ${ }^{93}$. The attribution to the Bronze Age, suggested by Debain-Francfort ${ }^{94}$ and supported by $\mathrm{Mei}^{95}$ and $\mathrm{Chen}^{96}$, was motivated by the discovery of some copper fragments and one knife (Figure 20). Although some items are distinctive, such as the Chust culture-type crescent-shaped knife, the lack of stratigraphic and archaeological contexts, not provide reliable basis to consider Aketala site a cultural centre.

87. Xinjiang Wenwu Kaogu Yanjiusuo, "Burials 151 and 152 at Wupu, in Hami, Xinjiang", Xinjiang Wenwu, no. 3 (1992): 1-13.

88. Shehui Xueyuan Kaogu Yanjiusuo, C14 Radiocarbon dates in Chinese archaeology (1965-1991), 1991.

89. J. Mei, Copper and Bronze Metallurgy in Late Prehistoric Xinjiang: Its Cultural Context and Relationship with Neighboring Regions, 22-23.

90. B. H. Wang, "A preliminary analysis of the archaeological cultures of the Bronze Age in the region of Xinjiang", 51-52.

91. Shehui Xueyuan Kaogu Yanjiusuo, C14 Radiocarbon dates in Chinese archaeology (1965-1991).

92. K. Han, "Anthropological Characteristics of the Human Skulls from the Ancient Cemetery, Gumugou, Xinjiang," Kaogu Xuebao, no. 3 (1986): 361-384.

93. Tulufan Wenwusuo [Tultural Institute of Turfan], "Burials in Subashen, Shanshan county, Xinjiang," Kaogu, no. 1 (1984): 41-51.

94. C. Debain-Francfort, "Archéologie du Xijiang des origines aux Han". Primere partie, 5-29.

95. J. Mei, Copper and Bronze Metallurgy in Late Prehistoric Xinjiang: Its Cultural Context and Relationship with Neighboring Regions, 9.

96. G. Chen, "Discussion on Xinjiang Archaeology," Tulufan xue Yanjiu, no. 1 (2002): 16-30. 


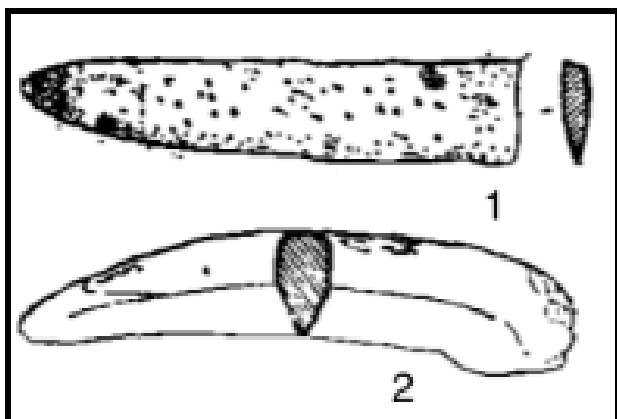

Figure 20. Copper Knife (1) and Chust Culture Crescent-shaped Stone Knife (2) from Aketala Site

Source: Xinjiang Wewu'er Zizhiqu Bowuguan Kaogudui, "Investigation in the Neolithic sites at Aketala etc., Shufu county, Xinjiang," Kaogu, no. 2 (1977): 107, fig. 2.

The Xiabandi cemetery AII was excavated in 2004 and, basing on the findings, archaeologists identified two phases. The early phase was represented by graves containing flat-bottomed jars with contracted neck, trumpet-shaped earrings and wide-band-shaped bracelets, similar to those of the Andronovo horizon. Distinctive objects of the later phase were the round-bottomed vessels, which resembled the ones found in the Xiangbaobao cemetery $\left(900-400\right.$ BCE) ${ }^{97}$ (Figure 21). On this basis, archaeologists dated the early phase to $1500-1300 \mathrm{BCE}$ and the later to 600 BCE. Little research has been conducted on the remains and at present no iron has been reported. Nevertheless, judging from the findings, the Xiabandi cemetery might have been used during the Bronze Age as well as the Iron Age.

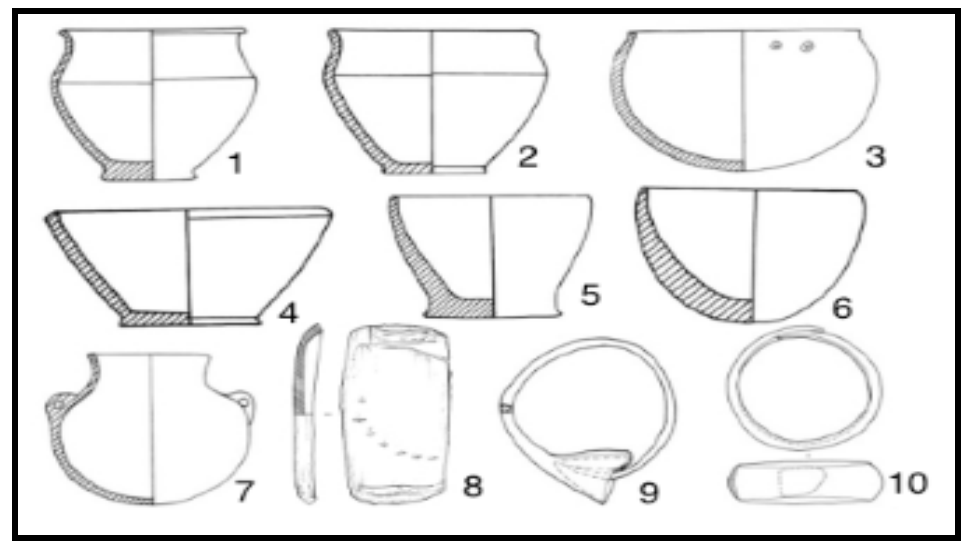

Figure 21. Grave Goods from Xiabandi Context of the Andronovo-type $(1,2,4,5,9,10)$ and Xiangbaobao-type $(3,6,7)$

Source: Y. Wu, "On the Bronze culture of Xiabandi cemetary in Kashi, Xinjiang," Xiyu yanjiu, no. 2 (2012): 41, fig. 3.

97. Y. Wu, "On the Bronze culture of Xiabandi cemetary in Kashi, Xinjiang," Xiyu yanjiu, no. 2 (2012): 41, fig. 3. 
The Xiangbaobao cemetery ${ }^{98}$ showed two different burial practices: cremation and inhumation. From the cremation-type burials very few objects were recovered: a copper ring, a piece of iron and several fragments of pottery and bones. These graves were assigned to the Iron Age. The inhumation-type graves contained pottery vessels, similar to the ones from the Tajikistan part of the Pamirs ${ }^{99}$, copper, bronze, iron and gold ornaments and implements. Etched beads of the Saka type were also recovered (Figure 22). The second group of Xiangbaobao graves, the richest recovered so far in the Xinjiang Pamirs region, was C14-dated to $900-400 \mathrm{BCE}^{100}$, it should be ascribed to the Iron Age.

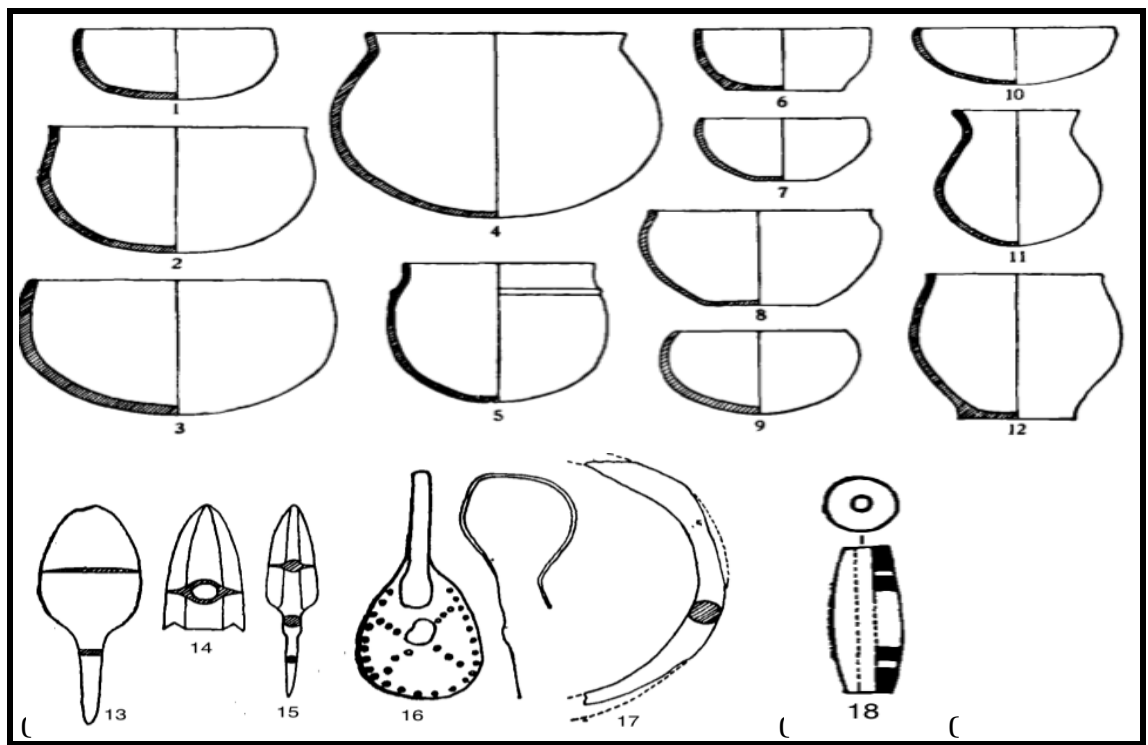

Figure 22. Funerary goods from Xiangbaobao Cemetery: Pottery Vessels (1-12), Bronze Implements (13-15), Gold Plaque (16), Iron Bracelet (17) and Etched Bead (18)

Source: Xinjiang Wenwu Kaogu Yanjiusuo, "On ancient cemetery in the Pamir Plateau," Kaogu Xuebao, no. 2 (1981): 207, fig. 13; 208, fig. 14; 210, fig. 15.

The region to the north of Kunlun Mountains has been little investigated. Until a few years ago, only its later phase was known, because of the discovery of two sites, Zahongluke and Shanpula, both ascribed to the Iron $\mathrm{Age}^{101}$. In the Zahongluke graves well-preserved desiccated corps,

98. Xinjiang Wenwu Kaogu Yanjiusuo, "On ancient cemetery in the Pamir Plateau," Kaogu Xuebao, no. 2 (1981): 199-216.

99. A. N. Bernshtam, Historical-Archaeological essay on the Central Tian Shan and Pamir-Altai Mountain Regions (Moscow: Akademii Nauk SSSR, 1952), 311.

100. Shehui Xueyuan Kaogu Yanjiusuo, C14 Radiocarbon dates in Chinese archaeology (1965-1991).

101. T. Shui, "On the relationship between the Tarim and Ferghana basins in the Bronze Age" in The Bronze Age and Early Iron Age Peoples of Eastern Central Asia vol. 1, ed. V. Mair, (Washington DC: Institute for the Study of Man, 1998), 166; K. Han, "The physical anthropology of the ancient populations of the Tarim Basin," in The Bronze Age and Early Iron Age Peoples of Eastern Central Asia vol. 2, ed. V. Mair, (Washington DC: Institute for the Study of Man, 1998), 563. 
covered by distinctive tattoos were found ${ }^{102}$. The grave goods were simple, consisting of wooden artefacts, plain pottery vessels, few copper objects and fragments of iron. The context was reported to be C14-dated to ca. 1000 $\mathrm{BCE}^{103}$. However, a closer to the reports reveals that the two cemeteries in Zahongluke village represent at least three different phases, from $1500 \mathrm{BCE}$ to $600 \mathrm{AD}$, the earlier being characterised by the absence of metal and wide use of wood for producing all kinds of objects ${ }^{104}$.

The Shanpula cemetery contained more than 50 graves, divided into single and group burials ${ }^{105}$. Funerary objects included handmade pottery similar to those of Xiangbaobao cemetery, bronze and iron tools. It was dated to $200 \mathrm{BCE}$ and ascribed to the Iron Age ${ }^{106}$.

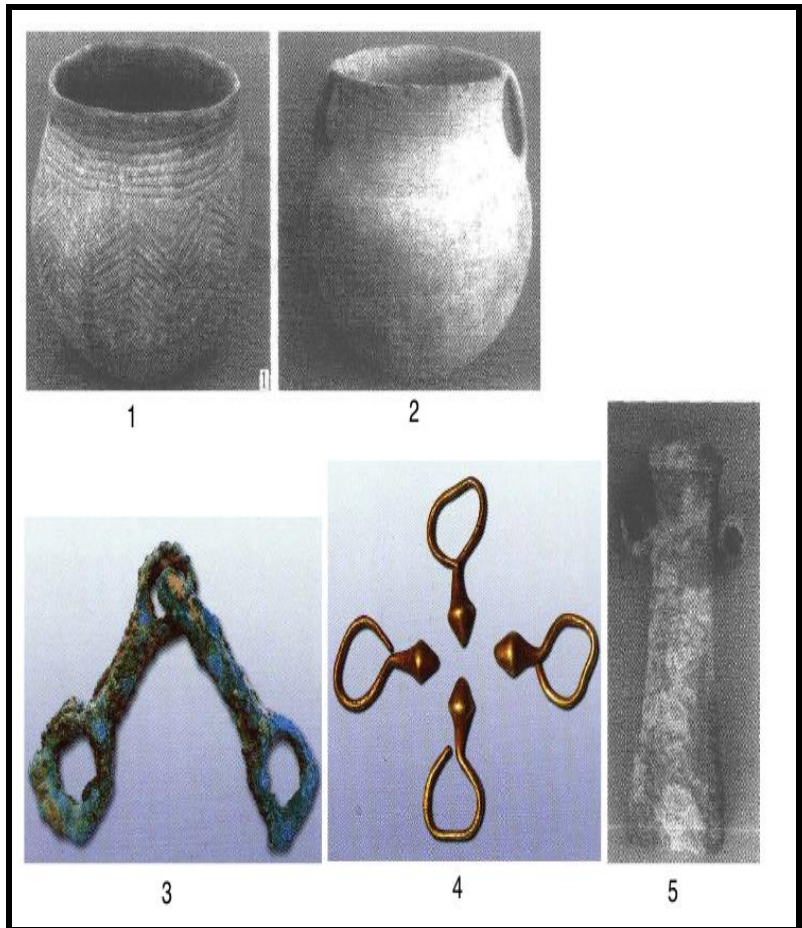

Figure 23. Grove Good from Liushi Cemetery: Pottery Vessels (1, 2) Copper Implements $(3,5)$ and Golden Earrings (6)

Source: Xinjiang Shehui Xueyuan Kaogu Yanjiusuo Xinjiangdui, "Bronze Age cemetery at Liushi, Yutian county, Xinjiang," Kaogu, no. 7 (2006): 40, figs. 1, 6, 3; 36, figs. 2 , 3.

102. D. He, "A brief report on the mummies from the Zaghunluq site in Charvhan county," in The Bronze Age and Early Iron Age Peoples of Eastern Central Asia vol. 1, ed. V. Mair, (Washington DC: Institute for the Study of Man, 1998), 169-174.

103 T. Shui, "On the relationship between the Tarim and Ferghana basins in the Bronze Age" in The Bronze Age and Early Iron Age Peoples of Eastern Central Asia vol. 1, ed. V. Mair, (Washington DC: Institute for the Study of Man, 1998), 166.

104. Xinjiang Wenwu Kaogu Yanjiusuo, "Report of the excavation of the n. 1 cemetery in Zahongluke village, Qiemo county, Xinjiang," Каogu Хиеbao, no. 1 (2003): 89-136; Xinjiang Bowuguan Kaogubu "Prelimiary report of the excavation of the n. 2 cemetery in Zahongluke, Qiemo county", 1-21.

105. W. Liu, "The burial system in Shampula cemetery" Xiyu yanjiu, no. 3 (2002). 50-55

106. K. Han, "The physical anthropology of the ancient populations of the Tarim Basin", 563. 
The Liushi cemetery represents the only Bronze Age site discovered so far in the southern rim of the Tarim Basin. It was dated by the archaeologists to $1000 \mathrm{BCE}^{107}$. The graves were all stone-enclosed earthen pits and contained unpainted, round and flat-bottomed pottery cups and handled jars, copper and bronze implements, decorations, mirrors, and stone beads (Figure 23). The cemetery yielded some iron and gold items (figure 22.6). The style of the pottery decorations and the metal ornaments resembled those from Saka contexts. Thus, the attribution of the Liushi site to the Bronze Age is questionable.

Very little has been researched in the southern part of the Tarim Basin and although it is clear that Bronze Age people occupied the area, the information is still insufficient to trace a geographical distribution as well as a cultural context for the remains.

\section{Discussion}

Divergences of opinions among scholars on the chronological and cultural attribution of the remains reflect the fact that the prehistory of Xinjiang, as a field of study, is still at its beginning, and numerous challenges remain to be overcome. However, some considerations on the current state of the research can be made.

First, as Wang Binghua ${ }^{108}$ suggested, although opinions on dates and cultural attributions often differ, the existence of two periods, Bronze Age and Iron Age, roughly dated to 2000-1000 BCE and 1000- $200 \mathrm{BCE}$ respectively, can be established.

Second, several sites, such as Qiemu'erqieke, Sidaogou, Subeixi, Yanbulake and Xiabandi, seem to have been in use for several centuries, thus they may represent both the Bronze Age and Iron Age (Table 3). The hypothesis of Hanqigou being the developed phase of Yanbulake, suggested by $\mathrm{Mei}^{109}$, should be further investigated. In general, micro-scale research on single areas should be encouraged in order to identify traces of the internal development of the site: these detailed studies could be useful when data are re-examined in the broader context of Eurasian prehistory.

107. Xinjiang Shehui Xueyuan Kaogu Yanjiusuo Xinjiangdui "Bronze Age cemetery at Liushi, Yutian county, Xinjiang", Kaogu, no. 7 (2006): 31-40.

108. B. H. Wang, "A preliminary analysis of the archaeological cultures of the Bronze Age in the region of Xinjiang," Xinjiang shehui kexue, no. 4 (1985): 50-61.

109 J. Mei, Copper and Bronze Metallurgy in Late Prehistoric Xinjiang: Its Cultural Context and Relationship with Neighboring Regions, 22. 
Table 3. Temporal-cultural Framework for the Remains Analyzed in this Paper

\begin{tabular}{|c|c|c|}
\hline & Bronze Age & Iron Age \\
\hline $\begin{array}{l}\text { ALTAY } \\
\text { MOUNTAINS }\end{array}$ & Qiemu'erqieke I: Abahe - Bu'erjin & Qiemu'erqieke II \\
\hline \multirow{2}{*}{$\begin{array}{l}\text { YILI VALLEY } \\
\text {-TACHENG } \\
\text { REGION }\end{array}$} & Weixiao & $\begin{array}{l}\text { Tiemulike: Zhongyangchang } \\
\text { Suodunbulake - Nulasai }\end{array}$ \\
\hline & Gongliu & $\begin{array}{l}\text { Heishantou } \\
\text { Yimuchang }\end{array}$ \\
\hline \multirow{4}{*}{$\begin{array}{l}\text { NORTHERN } \\
\text { TIANSHAN } \\
\text { MOUNTAINS } \\
\text { TURFAN- } \\
\text { BARKOL }\end{array}$} & Sidaogou: Banjiegou & Sidaogou \\
\hline & $\begin{array}{l}\text { Nanwan: Kuisu - Shirenzi } \\
\text { Junmachang - Ke'arsang (?) }\end{array}$ & $\begin{array}{l}\text { Alagou I: Yu'ergou - Dongfengchang - } \\
\text { Wulapo (?) } \\
\text { Alagou II }\end{array}$ \\
\hline & \multirow{2}{*}{ Shuinichang, Liangzhongfang } & Nanshan, Yinhongqiao (?) \\
\hline & & Dalongkou: Dacaotan \\
\hline \multirow{2}{*}{\begin{tabular}{|l|} 
SOUTHERN \\
TIANSHAN \\
MOUNTAINS \\
\end{tabular}} & Aketala: Quhui & Chawuhugou: Qunbake \\
\hline & Haladun & Baozidong: Kazi'ertu'er \\
\hline \multirow{2}{*}{ EAST XINJIANG } & Yanbulake & Yanbulake \\
\hline & Wupu & Hanqigou \\
\hline TARIM BASIN & Gumugou & \\
\hline $\begin{array}{l}\text { PAMIRS } \\
\text { HIGHLANDS }\end{array}$ & \begin{tabular}{|l|} 
Aketala \\
Xiabandi All
\end{tabular} & \begin{tabular}{|l|} 
Xiangbaobao \\
Xiabandi Al
\end{tabular} \\
\hline \multirow{2}{*}{$\begin{array}{l}\text { NORTHERN } \\
\text { KUNLUN } \\
\text { MOUNTAINS }\end{array}$} & \multirow{2}{*}{ Liushi } & Zahongluke \\
\hline & & Shanpula \\
\hline
\end{tabular}

Source: Author.

Third, according to the available material, northern and eastern Xinjiang, including the Tianshan range and Hami Basin, were inhabited earlier than their western and southern counterparts. In those regions early cemeteries, such as those of Qiemu'erqieke, Gumugou, Xintala, Yanbulake, present clear affiliations with northern populations of western Siberia and with Bronze Age cultures in Gansu. Gumugou burials present similarities with the ones of the Afanasevo horizon, while some funerary rites and grave goods in Qiemu'erqieke site resemble those of the Okunevo cultures. Andronovo-type bronze socketed axes and incised potteries were found in the Xintala site, while the S-shaped decorations on vessels at the Yanbulake cemetery are similar to those of Gansu Siba (2000-1600 BCE) and the Xindian culture (1500-1000 BCE). This material supports the hypothesis of nomadic populations from the north migrating to Xinjiang in the III-I millennium BCE, and the thesis that, at the same time, "technological knowledge" moved from China heartland to the north-westernmost side of the country.

\section{Conclusion: New Approaches and New Perspectives}

Judging from the current state of the research on prehistoric Xinjiang, the main current problems are the lack of clear standards for establishing archaeological cultures within the context of prehistoric Xinjiang ${ }^{110}$, on one

110. This observation was made in 1998 by An Zhimin in Z. An, "Cultural complexes of the Bronze Age in the Tarim Basin and surroundings areas," in The Bronze Age and 
side and the failure in re-examining micro-scale research in the wider Eurasian context, on the other.

Therefore, in the light of this study and considering the directions for future research, some major issues need to be emphasized:

1. The paleoenvironment, essential for arranging a safe ecological context for prehistoric cultures, is too little documented;

2. The establishment of a secure temporal framework is hampered by the low number of $\mathrm{C} 14$ analyses. Relative chronologies are also difficult to formulate, due to the lack of stratigraphic studies ${ }^{111}$;

3. Excavation reports are not regularly published and are often concise, neglecting pictures and drawings, preventing in some cases the correct interpretation of the remains. Scarcity of information also involves Stone Age remains depriving the research on the Bronze and Iron Ages of reliable bases;

4. Archaeological research is impacted by the "methodological weakness" detected by Roberts and Linden ${ }^{112}$ : despite being in theory based on the combination of several data, archaeological cultures have been often defined according to a single category of evidence, namely pottery for later prehistory. Discoveries in Xinjiang revealed a general scarcity of pottery, compared to other cultures, and in some cases, such as in Gumugou cemetery, no pottery was found. So, although it is clear that pottery alone cannot be the basis for identifying cultural groups in Xinjiang, an alternative is still to be found.

5. Because of the peculiar position of Xinjiang, prehistoric remains should be properly re-evaluated in the broader context of Eurasia. It is evident that nomad populations of Central Asia and western Siberia greatly contributed to the spread of cultural and technological innovations through different kinds of relationships with local people. The involvement of Xinjiang cultures in this system of connections is demonstrated by the presence of Afanasevo, Okunevo Andronovo cultural remains in the region. However numerous "missing links" still hamper the understanding of the scale, patterns, and mechanisms of these interactions, as well as the directions of the spread of cultural and technological innovations. To this respect communication and exchange of material among scholars from China, Russia and the rest of the world should improve, overcoming nationalistic sentiments and language barriers.

Despite the extraordinary scholarly effort in studying the complicated

Early Iron Age Peoples of Eastern Central Asia vol. 1, ed. V. Mair, (Washington DC: Institute for the Study of Man, 1998), 46-47.

111. Remains recovered by chance or during quick salvage excavations often lack of archaeological and stratigraphic contexts.

112. B. W. Roberts and M. V. Linden, Investigating Archaeological Cultures: material culture, variability, and transmission (Berlin: Springer 2011), 8. 
context of Xinjiang prehistory, much more is still to be learned: a multidisciplinary approach should be adopted, on one hand, while indigenous developments and external influences need to be equally investigated on the other. In doing so, a closer collaboration among scholars should be encouraged.

\section{Acknowledgments}

My thanks to Prof. Sabrina Rastelli for her methodological suggestions. I am also grateful to Prof. Liu Wensuo for having opened his personal library to me and for having shared with me precious information on the newest discoveries in Xinjiang.

\section{Bibliography}

An, Z. "Cultural complexes of the Bronze Age in the Tarim Basin and surroundings areas." In The Bronze Age and Early Iron Age Peoples of Eastern Central Asia vol. 1, Edited by V. Mair. Washington DC: Institute for the Study of Man, 1998.

Bernshtam, A. N. Historical-Archaeological essay on the Central Tian Shan and Pamiro-Alai Mountain Regions. Moscow: Akademii Nauk, 1952.

Boyd, W. E. and N. Chang. "Integrating social and environmental change in prehistory: a discussion of the role of landscape as a heuristic in defining prehistoric possibilities in NE Thailand". In Terra Australis: Altered ecologies - fire, climate and human influence on terrestrial landscapes, Edited by S. Haberle, J. Stevenson \& M. Prebble. Canberra: ANUE Press, 2010.

Chang, X. "Brief report on the excavation of n. 66 grave at the Nanwan cemetery in Balikun county." Xinjiang Wenwu, no. 1 (1985): 4-16.

Chang, X. "Investigation of the Neolithic site at Junmachang, Yiwu". Xinjiang Wenwu, no. 1 (1986): 14-15.

Chen, G. "A preliminary research on early cultures in Xinjiang". Zhongya Xuekan, no. 4 (1995): 5-72.

Chen, G. "Discussion on Xinjiang Archaeology". Tulufan xue Yanjiu, no. 1 (2002): 16-30.

Chen, G. "New ideas on the Neolithic cultures in Xinjiang". Kaogu, no. 4 (1987): 343-351.

Chen, G. "On the Bronze Age and Early Iron Age cultures of Xinjiang". Kaogu, no. 4 (1990): 366-374.

Chen, G. "Prehistoric cultures in Xinjiang". Xibei Minzu Yanjiu, no. 2 (1994): 101111.

Chen, G. "Several problems on the very ancient cultures in Xinjiang". Xinjiang Wenwu, no. 1 (1985): 27-38.

Chen, G. "Several problems on the very ancient cultures in Xinjiang". Xinjiang Wenwu, no. 1 (1985): 27-38.

Chen, G. "The Neolithic site at Banjiegou, Qitai county, Xinjiang." Kaogu, no. 6 (1981): 552-553.

Chen, G. "Western Region in prehistoric period". In Xiyu Tongshi, Edited by T. Yu. Zhengzhou: Zhengzhou Guji Chubanshe 1996. 
Chen, K. and T. H. Hiebert. "The Late prehistory of Xinjiang in relation to its neighbors". The Journal of World Prehistory 9, no. 2 (1995): 243-300.

Chinese Museum of History. Tianshan Gudao dongxifeng [East and West along the ancient Tianshan road]. Beijing: Zhongguo shehui chubanshe, 2002.

Debain-Francfort, C. "Archéologie du Xijiang des origines aux Han" Primere partie ["Archaeology of Xinjiang from the origin to the Han dynasty" First part]. Paléorient 14, no. 1 (1988): 5-29.

Debain-Francfort, C. "Archéologie du Xijiang des origines aux Han" IIéme partie ["Archaeology of Xinjiang from the origin to the Han dynasty" Second part]. Paléorient 15, no. 1 (1989): 183-213.

Debain-Francfort, C. "Les Saka du Xinjiang avant le Hans (20av-220ap): critères d'indentification [Saka people in Xinjiang before the Han period: criteria of identification]". In Nomades et sédentaires en Asie centrale : apports de l'archéologie et de l'etnologie: actes du Colloque franco-soviétique Alma Ata (Kazahkstan) 17-26 octobre 1987, Edited by H. P. Francfort. Paris: Centre National de la Recherche Scientifique 1990.

Han, J. "Traditions and chronological frameworks of the Bronze Age and early Iron Age cultures in Xinjiang". Xinjiang Wenwu, no. 3 (2005): 57-99.

Han, K. "Anthropological Characteristics of the Human Skulls from the Ancient Cemetery, Gumugou, Xinjiang." Kaogu Xuebao, no. 3 (1986): 361-384.

Han, K. "The physical anthropology of the ancient populations of the Tarim Basin." In The Bronze Age and Early Iron Age Peoples of Eastern Central Asia vol. 2, Edited by V. Mair. Washington DC: Institute for the Study of Man, 1998.

He, D. "A brief report on the mummies from the Zaghunluq site in Charvhan county." In The Bronze Age and Early Iron Age Peoples of Eastern Central Asia vol. 1, Edited by V. Mair. Washington DC: Institute for the Study of Man, 1998.

He, X. "The n. 95 grave at Nanwan, Balikun county, Xinjiang." Kaogu yu Wenwu, no. 5 (1987): 6-8.

Huang, W. Report of the archaeological excavations in Xinjiang (1957-1958). Beijing: Wenwu chubanshe, 1983.

Jia, P. and A. Betts. "A re-analysis of the Qiemu'erqieke (Shamirshak) cemeteries, Xinjiang, China". The Journal of Indo-European Studies 38, no. 3- 4 (2010): 275-317.

Kiselev, S. V. Ancient history of Southern Siberia. Moscow-Leningrad: Nauka, 1951.

Kovalev A. Earliest European in the heart of Asia: the Chemurchek cultural phenomen, vol. 1. Saint Petersburg: Book Antiqua, 2014.

Kovalev A. Earliest European in the heart of Asia: the Chemurchek cultural phenomen,vol. 2. Saint Petersburg: Book Antiqua, 2015.

Li, S. "Typological study on the bronze objects found in Aga'ersen, Yili river valley." Bianjiang Kaogu Yanjiu, no. 2 (2014): 99-110.

Li, Y. and H. Liu. "Ancient cemetery at Aidinghu,Tulufan, Xinjiang." Kaogu, no. 4 (1982): 365-72.

Liu, H. and H. Zhang. "Investigation of the Yiyayilake cemetery in Tuokexun county, Xinjiang." Kaogu, no. 7 (1985): 597-603.

Liu, H. and Y. Zhang. "Ancient cemetery at Kageqiake, Tuokexun county, Xinjiang". Kaogu, no. 7 (1987): 597-603.

Liu, W. "The burial system in Shampula cemetery." Xiyu yanjiu, no. 3 (2002): 5055. 
Mei, J. Copper and Bronze Metallurgy in Late Prehistoric Xinjiang: Its Cultural Context and Relationship with Neighboring Regions. Oxford: Archaeopress, 2000.

Moshkova, M. G. Steppe zone of the Asiatic part of the URSS in the ScythoSarmatian time. Moscow: Hayka, 1992.

Roberts, B. W. and M. V. Linden. Investigating Archaeological Cultures: material culture, variability, and transmission. Berlin: Springer, 2011.

Shehui Xueyuan Kaogu Yanjiusuo [Institute of Archaeology, Chinese Academy of Social Sciences]. C14 Radiocarbon dates in Chinese archaeology (19651991). Beijing: Wenwu chubanshe, 1991.

Shui, T. "A comparative study of the Bronze Age cultures in Xinjiang". Guoxue Yanjiu, no. 1 (1993): 447-490.

Shui, T. "On the relationship between the Tarim and Ferghana basins in the Bronze Age." In The Bronze Age and Early Iron Age Peoples of Eastern Central Asia vol. 1, Edited by V. Mair. Washington DC: Institute for the Study of Man, 1998.

Stein, A. Innermost Asia: Detailed Report of Explorations in Central Asia, Kan-su and Eastern Iran. Oxford: Clarendon Press, 1928.

Tulufan Wenwusuo [Tultural Institute of Turfan]. "Burials in Subashen, Shanshan county, Xinjiang." Kaogu, no. 1 (1984): 41-51.

Thorthon, C. and T. Shurr. "Genes, language and culture: an example from the Tarim basin." Oxford Journal of Archaeology 23, no. 1 (2004): 83-106.

Wang, B. and X. Chang. "The investigation and excavation of the ancient tombs at Baozidong, in Wensu county". Xinjiang Wenwu, no. 2 (1986): 1-13.

Wang, B. and Z. Cheng. "A group of bronze artifacts unearthed in Gongliu county". Xinjiang Wenwu, no. 8 (1989): 95-96.

Wang, B. H. "A preliminary analysis of the archaeological cultures of the Bronze Age in the region of Xinjiang". Xinjiang shehui kexue, no. 4 (1985): 50-61.

Wang, B. H. "A brief report of the excavation of burials with wooden chambers at Alagou, Xinjiang." Wenwu, no. 1 (1981): 18-22.

Wang, B. H. "Recherches historiques prélimiaires sur les Saka du Xinjiang ancient" ["Preliminary historical research on Saka people in ancient Xinjiang"]. Arts Asiatiques, no. 42 (1987): 31-44.

Wang, B. Study of grassland stone stele on the Silk Road. Urumqi: Xinjiang People's Press 1995.

$\mathrm{Wu}, \mathrm{Y}$. "On the Bronze culture of Xiabandi cemetary in Kashi, Xinjiang." Xiyu yanjiu, no. 2 (2012): 36-43.

Xinjiang Bowuguan Kaogubu [Department of Archaeology of the Xinjiang Museum]. "Prelimiary report of the excavation of the n. 2 cemetery in Zahongluke, Qiemo county." Xinjiang Wenwu, nos. 1, 2 (2002): 1-21.

Xinjiang Shehui Xueyuan Kaogu Yanjiusuo Xinjiangdui [Xinjiang archaeological team, Institute of Archaeology, Chinese Academy of Social Science]. "A preliminary report on the first excavation of ancient tombs at Qunbake, Luntai, Xinjiang". Kaogu, no. 11 (1987): 987-996.

Xinjiang Shehui Xueyuan Kaogu Yanjiusuo Xinjiangdui [Xinjiang archaeological team, Institute of Archaeology, Chinese Academy of Social Science]. "Report on the excavation of the cemetery II at Chawuhu pass, Hejing county Xinjiang". Kaogu, no. 6 (1990): 511-518.

Xinjiang Shehui Xueyuan Kaogu Yanjiusuo Xinjiangdui [Xinjiang archaeological team, Institute of Archaeology, Chinese Academy of Social Science]. "A brief report of the second and third excavations of ancient tombs at Qunbake, Luntai, Xinjiang." Kaogu, no. 8 (1991): 684-703. 
Xinjiang Shehui Xueyuan Kaogu Yanjiusuo Xinjiangdui [Xinjiang archaeological team, Institute of Archaeology, Chinese Academy of Social Science]. "Bronze Age cemetery at Liushi, Yutian county, Xinjiang". Kaogu, no. 7 (2006): 3140.

Xinjiang Weiyu'er Zizhiqu Wenhuating Wenwuchu [Cultural Relicts Office Xinjiang Authonomous Region]. "The Sidaogou site in Mulei county Xinjiang". Kaogu, no. 2, (1982): 113-120.

Xinjiang Weiyu'er Zizhiqu Wenhuating Wenwuchu [Cultural Relicts Office Xinjiang Authonomous Region]. "The Yanbulake cemetery in Hami, Xinjiang". Kaogu Xuebao, no. 3, (1989): 325-362.

Xinjiang Wenwu Kaogu Yanjiusuo [Xinjiang Institute of Archaeology] "Summary of excavation at Qiemu'erqieke cemetery". Wenwu, no. 1 (1981): 23-32.

Xinjiang Wenwu Kaogu Yanjiusuo [Xinjiang Institute of Archaeology]. "On ancient cemetery in the Pamir Plateau." Kaogu Xuebao, no. 2 (1981): 199-216.

Xinjiang Wenwu Kaogu Yanjiusuo [Xinjiang Institute of Archaeology]. "Stone cist tomb at Zhongyangchang, Gongnaisi, Xinyuan, Xinjiang". Kaogu yи Wenwu, (1985): 21-6.

Xinjiang Wenwu Kaogu Yanjiusuo [Xinjiang Institute of Archaeology]. "The rockfill tombs discovered at Dacaotan, Miquan, Xinjiang." Kaogu yu Wenwu, no. 1 (1986): 36-38.

Xinjiang Wenwu Kaogu Yanjiusuo [Xinjiang Institute of Archaeology] "Brief report of the excavation in 1986 of the cemetery IV at Chawuhugou, Hejing county Xinjiang." Xinjiang Wenwu, no. 1 (1987): 1-9.

Xinjiang Wenwu Kaogu Yanjiusuo [Xinjiang Institute of Archaeology] "Tiemulike cemetery, Xinyuan, Xinjiang". Wenwu, no. 8 (1988): 59-66.

Xinjiang Wenwu Kaogu Yanjiusuo [Xinjiang Institute of Archaeology]. "Brief report on the excavation in 1987 of the cemetery IV at Chawuhugou pass, Hejing county, Xinjiang." Xinjiang Wenwu, no. 4 (1988): 1-28.

Xinjiang Wenwu Kaogu Yanjiusuo [Xinjiang Institute of Archaeology] "The excavation of the cemetery II at Chawuhugou, Hejing county, Xinjiang". Xinjiang Wenwu, no. 4 (1989): 12-33.

Xinjiang Wenwu Kaogu Yanjiusuo [Xinjiang Institute of Archaeology]. "Brief report of the examination of ancient cemetery at Yanghai". Xinjiang Wenwu, no. 4 (1989): 34-41.

Xinjiang Wenwu Kaogu Yanjiusuo [Xinjiang Institute of Archaeology]. "Brief report of the excavation of the cemetery I at Chawuhugou, Hejing county Xinjiang". Xinjiang Wenwu, no. 4 (1992): 11-64.

Xinjiang Wenwu Kaogu Yanjiusuo [Xinjiang Institute of Archaeology]. "Brief report of the excavation of the cemetery $\mathrm{V}$ at Chawuhugou, Hejing county Xinjiang." Xinjiang Wenwu, no. 2 (1992): 15-30.

Xinjiang Wenwu Kaogu Yanjiusuo [Xinjiang Institute of Archaeology] "Burials 151 and 152 at Wupu, in Hami, Xinjiang." Xinjiang Wenwu, no. 3 (1992): 113.

Xinjiang Wenwu Kaogu Yanjiusuo [Xinjiang Institute of Archaeology]. "Brief report of the excavation of the cemetery I at Subeixi, Shanshan county Xinjiang". Xinjiang Wenwu, no. 4 (1993): 1-13.

Xinjiang Wenwu Kaogu Yanjiusuo [Xinjiang Institute of Archaeology]. "Ancient tombs in Shihezi city." Xinjiang Wenwu, no. 4 (1994): 12-19.

Xinjiang Wenwu Kaogu Yanjiusuo [Xinjiang Institute of Archaeology]. "Ancient cemetery at Suodunbulake in Chabucha'er county." Xinjiang Wenwu, no. 2 (1995): 1-19. 
Xinjiang Wenwu Kaogu Yanjiusuo [Xinjiang Institute of Archaeology]. "Ancient cemetery in Dalongkou, Jemusa'er county". Kaogu, no. 9 (1997): 39-45.

Xinjiang Wenwu Kaogu Yanjiusuo [Xinjiang Institute of Archaeology]. "General report on the investigation at Shihezi city". Xinjiang Wenwu, no. 4 (1998): 54-64.

Xinjiang Wenwu Kaogu Yanjiusuo [Xinjiang Institute of Archaeology] "Excavation of the Xintala site, Heshuo, Xinjiang". Kaogu, no. 5 (1988): 399-407.

Xinjiang Wenwu Kaogu Yanjiusuo [Xinjiang Institute of Archaeology]. "Ancient graves in Nanshan, Shihezi county, Xinjiang". Wenwu, no. 8 (1999): 38-47.

Xinjiang Wenwu Kaogu Yanjiusuo [Xinjiang Institute of Archaeology]. "New result of archeological survay in Yanghai cemetery, Shanshan county, Xinjiang." Kaogu, no. 5 (2002): 3-7.

Xinjiang Wenwu Kaogu Yanjiusuo [Xinjiang Institute of Archaeology]. "Report of the first excavation in Kezi'ertu'er cemetery, Baicheng county, Xinjiang". Kaogu, no. 6 (2002): 14-30.

Xinjiang Wenwu Kaogu Yanjiusuo [Xinjiang Institute of Archaeology]. "Report of the excavation of the $n$. 1 cemetery in Zahongluke village, Qiemo county, Xinjiang." Kaogu Xuebao, no. 1 (2003): 89-136.

Xinjiang Wenwu Kaogu Yanjiusuo [Xinjiang Institute of Archaeology]. "On the remains in Yu'ergou and the cemetery in Alagou, Urumqi". Kaogu, no. 4 (2014): 19-35.

Xinjiang Wewu'er Zizhiqu Bowuguan Kaogudui [Archaeological team of Museum of Xinjiang Uygur authonomous region]. "Investigation in the Neolithic sites at Aketala etc., Shufu county, Xinjiang". Kaogu, no. 2 (1977): 107-110.

Yablosky, L. T. "The material culture of the Saka and historical reconstruction." In Nomads of the Eurasian Steppe in the Iron Age, Edited by J. Davis-Kimball, V. A. Bashilov and L. T. Yablosky. Berekly: Zinat Press, 1995.

Zhang, Y. "Archeological investigation and study of Alagou in the Tianshan mountians". Xibei Shidi, no. 3 (1987): 106-116.

Zhang, Y. "The discovery and study of the tombs in the Yili valley". Xinjiang Wenwu, no. 3 (1989): 11-22.

Zhou, J. and W. Li. "Ancient burials at Sazi village, Tuoli county". Xinjiang Wenwu, no. 2 (1996): 14-22. 
